\title{
Nicotinamide mononucleotide (NMN) supplementation promotes anti-aging miRNA expression profile in the aorta of aged mice, predicting epigenetic rejuvenation and anti-atherogenic effects
}

\author{
Tamas Kiss • Cory B. Giles • Stefano Tarantini • Andriy Yabluchanskiy • \\ Priya Balasubramanian • Tripti Gautam • Tamas Csipo • Ádám Nyúl-Tóth • \\ Agnes Lipecz • Csaba Szabo • Eszter Farkas • Jonathan D. Wren • Anna Csiszar • \\ Zoltan Ungvari 1
}

Received: 8 July 2019 / Accepted: 21 August 2019 /Published online: 28 August 2019

(C) American Aging Association 2019

\begin{abstract}
Understanding molecular mechanisms involved in vascular aging is essential to develop novel interventional strategies for treatment and prevention of
\end{abstract}

Tamas Kiss, Cory B. Giles and Stefano Tarantini contributed equally to this work.

T. Kiss - C. B. Giles - S. Tarantini - A. Yabluchanskiy • P. Balasubramanian · T. Gautam • T. Csipo · Á. Nyúl-Tóth • A. Lipecz $\cdot$ J. D. Wren $\cdot$ A. Csiszar $\cdot$ Z. Ungvari $(\bowtie)$ Vascular Cognitive Impairment and Neurodegeneration Program, Reynolds Oklahoma Center on Aging/Department of Geriatric Medicine, University of Oklahoma Health Sciences Center, 975 NE 10th Street, BRC 1311, Oklahoma City, OK 73104, USA e-mail: zoltan-ungvari@ouhsc.edu

T. Kiss • T. Csipo • A. Lipecz • E. Farkas • A. Csiszar • Z. Ungvari

Department of Medical Physics and Informatics / Theoretical Medicine Doctoral School, University of Szeged, Szeged, Hungary

\section{B. Giles · J. D. Wren}

Oklahoma Medical Research Foundation, Genes \& Human Disease Research Program, Oklahoma City, OK and Department of Biochemistry and Molecular Biology, University of Oklahoma Health Science Center, Oklahoma City, OK, USA

S. Tarantini · A. Yabluchanskiy · A. Csiszar · Z. Ungvari Translational Geroscience Laboratory, Department of Geriatric Medicine, University of Oklahoma Health Sciences Center, Oklahoma City, OK, USA age-related vascular pathologies. Recent studies provide critical evidence that vascular aging is characterized by $\mathrm{NAD}+$ depletion. Importantly, in aged mice, restoration of
A. Yabluchanskiy $\cdot$ A. Csiszar $\cdot$ Z. Ungvari

The Peggy and Charles Stephenson Cancer Center, University of Oklahoma Health Sciences Center, Oklahoma City, OK 73104, USA

T. Csipo · A. Lipecz $\cdot$ Z. Ungvari Department of Public Health / Doctoral School of Basic and Translational Medicine, Semmelweis University, Budapest, Hungary

Á. Nyúl-Tóth

Institute of Biophysics, Biological Research Centre / Theoretical Medicine Doctoral School, Hungarian Academy of Sciences, Szeged, Hungary

C. Szabo

Chair of Pharmacology, Department of Medicine, University of Fribourg, Fribourg, Switzerland

A. Csiszar

Institute of Human Physiology and Clinical Experimental Research, Semmelweis University, Budapest, Hungary

Z. Ungvari

Department of Health Promotion Sciences, College of Public Health, University of Oklahoma Health Sciences Center, Oklahoma City, OK, USA 
cellular NAD+ levels by treatment with the NAD+ booster nicotinamide mononucleotide (NMN) exerts significant vasoprotective effects, improving endothelium-dependent vasodilation, attenuating oxidative stress, and rescuing age-related changes in gene expression. Strong experimental evidence shows that dysregulation of microRNAs (miRNAs) has a role in vascular aging. The present study was designed to test the hypothesis that age-related NAD+ depletion is causally linked to dysregulation of vascular miRNA expression. A corollary hypothesis is that functional vascular rejuvenation in NMN-treated aged mice is also associated with restoration of a youthful vascular miRNA expression profile. To test these hypotheses, aged (24-month-old) mice were treated with NMN for 2 weeks and miRNA signatures in the aortas were compared to those in aortas obtained from untreated young and aged control mice. We found that protective effects of NMN treatment on vascular function are associated with antiaging changes in the miRNA expression profile in the aged mouse aorta. The predicted regulatory effects of NMNinduced differentially expressed miRNAs in aged vessels include anti-atherogenic effects and epigenetic rejuvenation. Future studies will uncover the mechanistic role of miRNA gene expression regulatory networks in the antiaging effects of NAD+ booster treatments and determine the links between miRNAs regulated by NMN and sirtuin activators and miRNAs known to act in the conserved pathways of aging and major aging-related vascular diseases.

Keywords Senescence - Atherosclerosis · Vascular cognitive impairment - Epigenetics · Vascular aging . Endothelial dysfunction - Oxidative stress

\section{Introduction}

Age-related diseases of the cardiovascular system are a leading cause of morbidity and mortality in the elderly (Abdellatif et al. 2018; Minamino and Komuro 2007; Wang and Bennett 2012; Alfaras et al. 2016; Ungvari et al. 2018). Vascular aging is associated with stiffening of the large arteries, endothelial dysfunction, oxidative stress, and inflammation, promoting the development of atherosclerotic vascular diseases (ischemic heart diseases, stroke, peripheral artery disease) and aorta aneurysm (Wang and Bennett 2012; Ungvari et al. 2018). Microvascular aging is also a major contributing factor to the pathogenesis of vascular cognitive impairment (VCI),
Alzheimer's disease, cerebral microhemorrhages, sarcopenia, heart failure, chronic kidney disease and (Ungvari et al. 2018; Mullins et al. 2014; Ungvari et al. 2017a; Toth et al. 2017; Tarantini et al. 2017a; Tarantini et al. 2016a; Sagare et al. 2013; Sweeney et al. 2018; Montagne et al. 2017; Kisler et al. 2017; Payne 2006; Hoenig et al. 2008; Long et al. 2012). Understanding molecular mechanisms involved in vascular aging is essential to develop novel interventional strategies for treatment and prevention of age-related vascular pathologies.

MicroRNAs (miRNA) are short, endogenous, noncoding transcripts that repress gene expression at the post-transcriptional level in both physiological and pathological conditions. Strong experimental evidence suggest that miRNAs have a role in regulation of lifespan in model organisms (Boehm and Slack 2005; Grillari and GrillariVoglauer n.d.; Ibanez-Ventoso et al. 2006) and that alterations in cellular miRNA expression profile also play a role in mammalian aging (Bates et al. n.d.; Maes et al. 2008; Inukai et al. 2012; Inukai and Slack 2013; Ito et al. 2010; Mercken et al. 2013; Smith-Vikos and Slack 2012; Ungvari et al. 2013a; Zhang et al. 2012; Zovoilis et al. 2011; Smith-Vikos et al. 2016; ElSharawy et al. 2012). Importantly, miRNAs were also reported to regulate several important aspects of endothelial biology and vascular function (Bonauer et al. 2009; Doebele et al. n.d.; Kuehbacher et al. 2007; Chen et al. 2015a; Hergenreider et al. 2012; Kim et al. 2014; Leung et al. 2013; Lovren et al. 2012; O'Rourke and Olson 2011; Rotllan et al. 2013; Stellos and Dimmeler 2014; Weber et al. 2014; Zampetaki et al. 2014). Several studies have demonstrated that agerelated miRNA dysregulation importantly contributes to the development of vascular aging phenotypes (Ito et al. 2010; Ungvari et al. 2013a,b; Menghini et al. 2014; Badi et al. 2018; Guo et al. 2017; Hazra et al. 2016; Regina et al. 2016; Boon et al. 2013; Csiszar et al. 2014) and promotes the pathogenesis of atherosclerotic diseases (Ono et al. 2011) encompassing every step from sterile vascular inflammation, plaque formation to plaque destabilization and rupture (Hartmann et al. 2016; Lu et al. 2018; Zhang et al. 2018). Dysregulation of miRNA expression has also been linked to microvascular aging phenotypes, including impaired angiogenesis (Ungvari et al. 2013b; Csiszar et al. 2014; Che et al. 2014; Jansen et al. 2015). Experimental interventions that both extend lifespan and prevent/delay age-related vascular dysfunction in rodents, including caloric restriction (Csiszar et al. 2014) and induction of earlylife IGF-1 deficiency (Tarantini et al. 2016b), were shown to reverse aging-induced alterations in vascular miRNA 
expression. Despite these advances, fundamental cellular and molecular processes of aging that are responsible for dysregulation of vascular miRNA expression have not been elucidated.

$\mathrm{NAD}^{+}$is a rate-limiting co-substrate for sirtuin enzymes, which are key regulators of pro-survival pathways in the vasculature (Das et al. 2018; Csiszar et al. 2009a; Csiszar et al. 2009b; Csiszar et al. 2008). Aging is associated with cellular $\mathrm{NAD}^{+}$depletion (Gomes et al. 2013; Massudi et al. 2012), which has been proposed to be a critical driving force of aging processes. In support of this theory, it was demonstrated that enhancing $\mathrm{NAD}^{+}$biosynthesis extends lifespan in lower organisms (Anderson et al. 2002) and improves health-span in mouse models of aging (Mitchell et al. 2018). Recent studies provide critical evidence that vascular aging is also characterized by NAD+ depletion (Tarantini et al. 2019; Csiszar et al. 2019; Kiss et al. 2019). Importantly, we 69 and other laboratories demonstrated (Das et al. 2018; de Picciotto et al. 2016) that in aged mice restoration of cellular $\mathrm{NAD}^{+}$ levels by treatment with the NAD+ precursor nicotinamide mononucleotide (NMN) (Yoshino et al. 2018) confers potent anti-aging vascular effects, reversing endothelial dysfunction, improving mitochondrial function, and attenuating oxidative stress.

The present study was designed to test the hypothesis that age-related NAD+ depletion is causally linked to dysregulation of vascular miRNA expression. A corollary hypothesis is that functional vascular rejuvenation in NMN-treated aged mice is also associated with restoration of a youthful vascular miRNA expression profile. To test these hypotheses, aged mice were treated with NMN for 2 weeks and miRNA signatures in the aortas were compared to those in aortas obtained from untreated young and aged control mice.

\section{Methods}

Animals, NMN supplementation

Young (3-month-old) and aged (24-month-old) male C57BL/6 mice were purchased from the aging colony maintained by the National Institute on Aging at Charles River Laboratories (Wilmington, MA). The biological age of 24-month-old mice corresponds to that of $\sim 60$-year-old humans. Mice were housed under specific pathogen-free barrier conditions in the Rodent Barrier Facility at University of Oklahoma
Health Sciences Center under a controlled photoperiod (12 h light; $12 \mathrm{~h}$ dark) with unlimited access to water and were fed a standard AIN-93G diet (ad libitum). Mice in the aged cohort were assigned to two groups. One group of the aged mice was injected daily with NMN (i.p. injections of $500 \mathrm{mg} \mathrm{NMN} / \mathrm{kg}$ body weight per day) or the equivalent volume of PBS for 14 consecutive days at 6 PM and 8 AM on day 14 and were sacrificed $4 \mathrm{~h}$ after last injection. Similar dosages of NMN have been shown to exert potent anti-aging effects on mouse health span (de Picciotto et al. 2016). All procedures were approved by the Institutional Animal Use and Care Committees of the University of Oklahoma Health Sciences Center. All animal experiments complied with the ARRIVE guidelines and were carried out in accordance with the National Institutes of Health guide for the care and use of Laboratory animals (NIH Publications No. 8023, revised 1978). The effects of NMN treatment on cognitive function, cerebromicrovascular responses, and aorta endothelial function in the same cohort of mice have been recently reported (Tarantini et al. 2019).

Quantitative real-time RT-PCR and miRNA expression profiling

A quantitative real time RT-PCR technique was used to analyze miRNA expression profiles in the aorta of mice from each experimental group as reported (Ungvari et al. 2013b; Csiszar et al. 2014; Tarantini et al. 2016b). In brief, total RNA was isolated with a mirVana ${ }^{\mathrm{TM}}$ miRNA Isolation Kit (ThermoFisher Scientific) and was reverse transcribed using TaqMan ${ }^{\circledR}$ MicroRNA Reverse Transcription Kit as described previously (Ungvari et al. 2013b; Csiszar et al. 2014; Tarantini et al. 2016b). The expression profile of mouse miRNAs in aortas derived from young and aged control mice and aged NMNtreated mice was analyzed using the TaqMan Array Rodent MicroRNA A+B Cards Set v3.0 (ThermoFisher Scientific). The qPCR data were quantified using the $\Delta \Delta \mathrm{Ct}$ method (Livak and Schmittgen 2001). Predicted and experimentally validated microRNA targets were obtained from the TargetScan database (Agarwal et al. 2015), and Gene Ontology enrichment analysis was performed on differentially expressed microRNA targets using Fisher's exact test between TargetScan targets and annotations from the Gene Ontology database (Harris et al. 2004). To identify relationships between miRNA targets and terms in the biomedical literature, we utilized 
the IRIDESCENT system (Wren and Garner 2004). IRIDESCENT uses a statistical model to determine whether each target gene co-occurs with a term of interest more frequently than would be expected by chance, and quantifies this in terms of the mutual information measure.

\section{Results}

Changes in vascular miRNA expression profile in mice associated with aging and with NMN treatment

We assessed changes in miRNA expression in the mouse aorta associated with aging and with NMN treatment. Hierarchical clustering (Fig. 1a) and principal component analysis (Fig. 1b) of miRNA expression showed a clear separation between the young and aged groups. Aged control mice and aged NMN-treated mice were also separated in the principal component analysis and hierarchical clustering. In contrast, miRNA expression in young mice and NMN-treated aged mice was similar and these groups did not separate well in the principal component analysis and hierarchical clustering. The Venn diagram in Fig. 1c shows that expression of several miRNAs, which are differentially expressed in the aortas of young and aged mice, was restored to youthful levels in aortas of NMN-treated aged mice. These data suggest that $\mathrm{NAD}^{+}$depletion has a critical role in age-related dysregulation of vascular miRNA expression. Figure 2 shows changes in expressions of individual miRNAs in the mouse aorta associated with age and NMN treatment.

Since the discovery of miRNA regulation of genes, several studies have been focused on predicting the biologically relevant target genes for miRNAs. We have used TargetScan database to predict putative biological targets of miRNAs differentially expressed with age whose expression is restored to youthful levels in aortas of aged mice by NMN supplementation (Table 1). GO terms enriched among miRNAs differentially expressed with age whose expression is restored to youthful levels in aortas of aged mice by NMN supplementation are shown in Table 2 . Analysis of the differentially expressed miRNAs indicated that a statistically significant number of them had target sites within genes associated with pathways regulating the intracellular signaling, protein homeostasis, and inflammation (Table 2). The results are consistent with the predicted anti-aging effects of NMN treatment. a

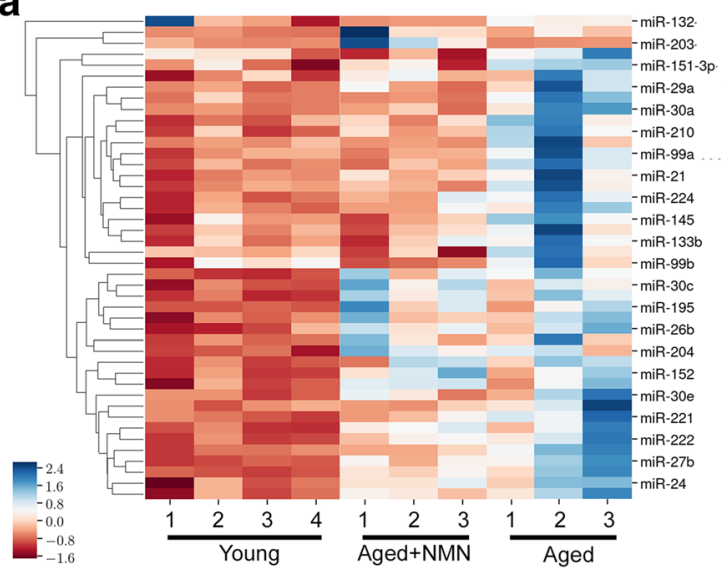

b

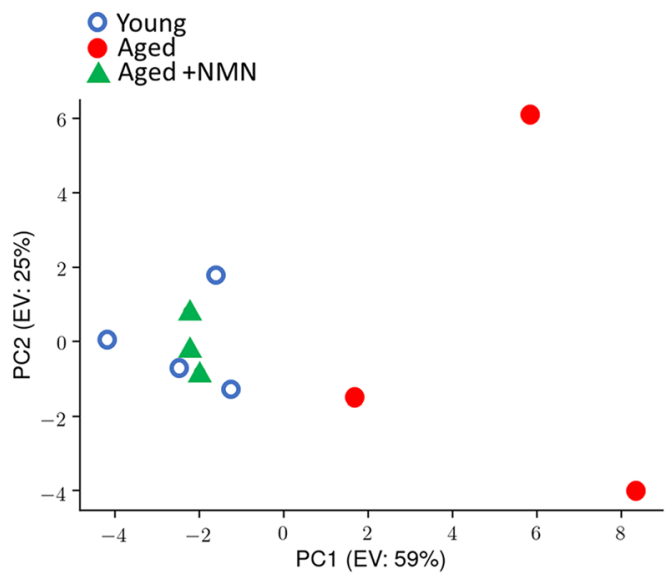

C

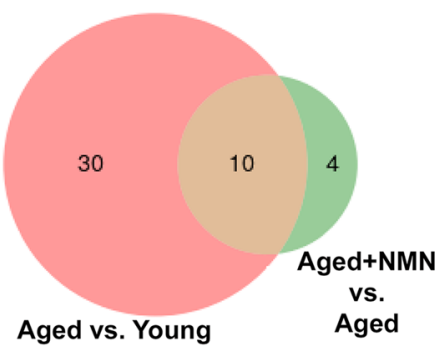

Fig. 1 NMN treatment reverses age-related changes in miRNA expression profile in the mouse aorta. a The heat map is a graphic representation of normalized miRNA expression values in aortas derived from young (3-month-old), aged (24-month-old), and NMNtreated aged mice. Hierarchical clustering analysis revealed the similarities on miRNA expression profiles of aortas from young and NMNtreated aged mice. b Principal component analysis (PCA) plot of miRNA expression profiles from aortas derived from young, aged control, and NMN-treated aged mice. The profiles from aged mice (red dots) cluster separately to clusters representative of young mice (blue circles) and NMN-treated aged mice (green triangles). PC1 and PC2: Principal components 1 and 2, respectively. c Venn diagrams showing the differentially expressed miRNAs in each group, which are significantly up- or down-regulated in aortas from aged mice compared to those from young mice or aged $\mathrm{NMN}$-treated mice 

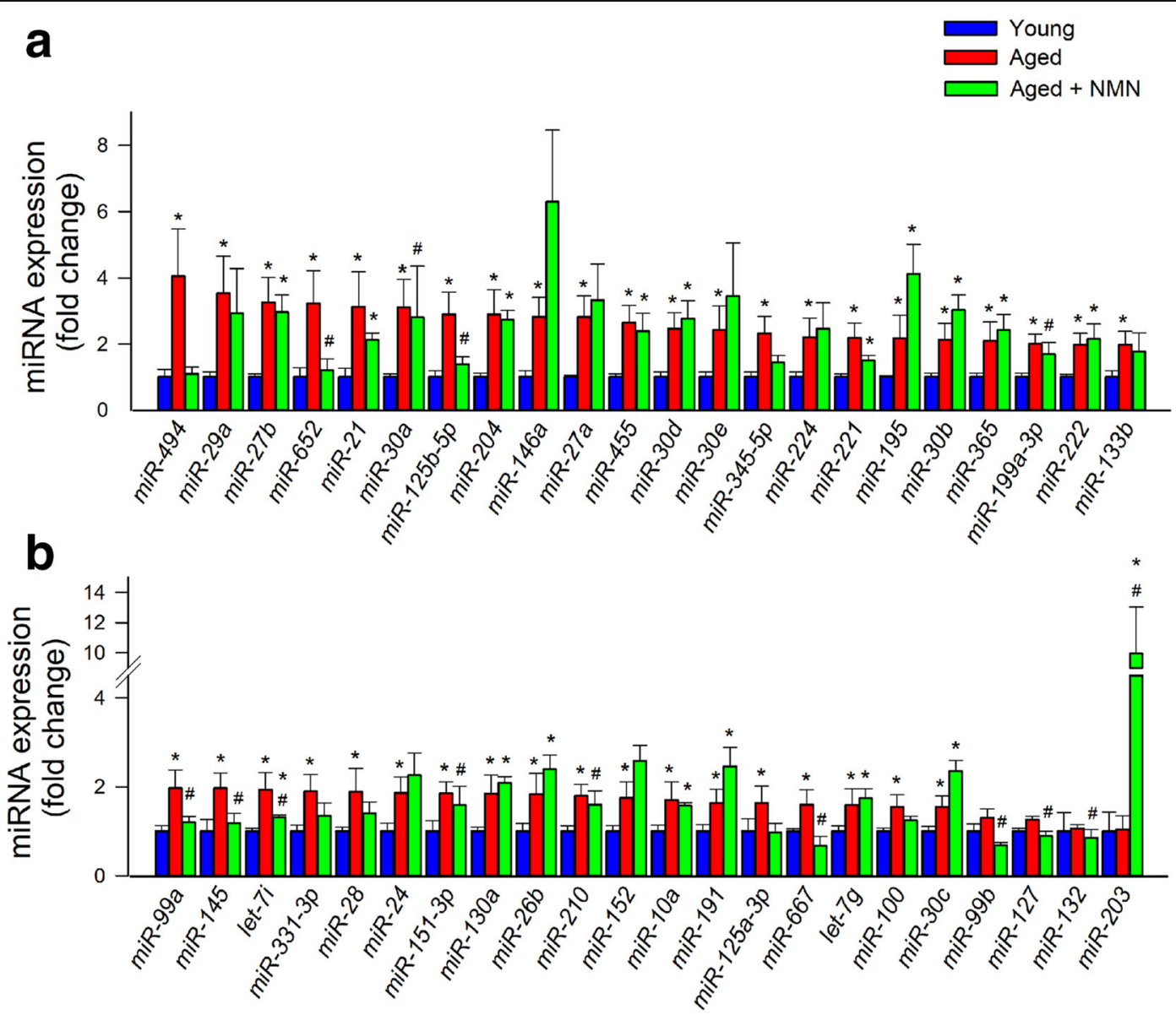

Fig. 2 Effects of aging and NMN treatment on miRNA expression in the mouse aorta. a, b qPCR data showing miRNA expression in aortas isolated from young (3-month-old), aged (24-month-

We also attempted to predict the biological effects of the differentially expressed miRNAs by identifying relationships between miRNA targets and terms in the biomedical literature utilizing the IRIDESCENT system (Wren and Garner 2004). The results of this analysis suggest that NMN supplementation likely promotes epigenetic rejuvenation and confers anti-atherogenic effects (Table 3 ).

\section{Discussion}

Our study demonstrates that protective effects of NMN treatment on vascular function is associated with antiaging changes in the miRNA expression profile in the aorta in a mouse model of aging that recapitulates old), and NMN-treated aged mice. Data are mean \pm S.E.M. $(n=3-$ 4 for each data point). $* P<0.05$ vs. young; $\# P<0.05$ vs. aged

vascular alterations and deficits present in elderly humans at risk for cardiovascular and cerebrovascular diseases.

Age-related changes in vascular miRNA expression likely play important pathogenic roles targeting critical signaling pathways, inflammatory processes, and cellular mechanisms involved in protein homeostasis and thereby impairing the structural and functional integrity of the vasculature (Fig. 3). Among others, miR-29a (Huang et al. 2016), miR-27b (Signorelli et al. 2016), miR-652 (Pilbrow et al. 2014), miR-221 (Wei et al. 2013), miR-28 (Wang et al. 2017), miR-21 (Urbich et al. 2008), miR-125b5p (Ohukainen et al. 2015), miR-494 (Wezel et al. 2015), and miR-145 (Faccini et al. 2017), which are up-regulated in aging, have been implicated in vascular inflammation and atherogenesis. 


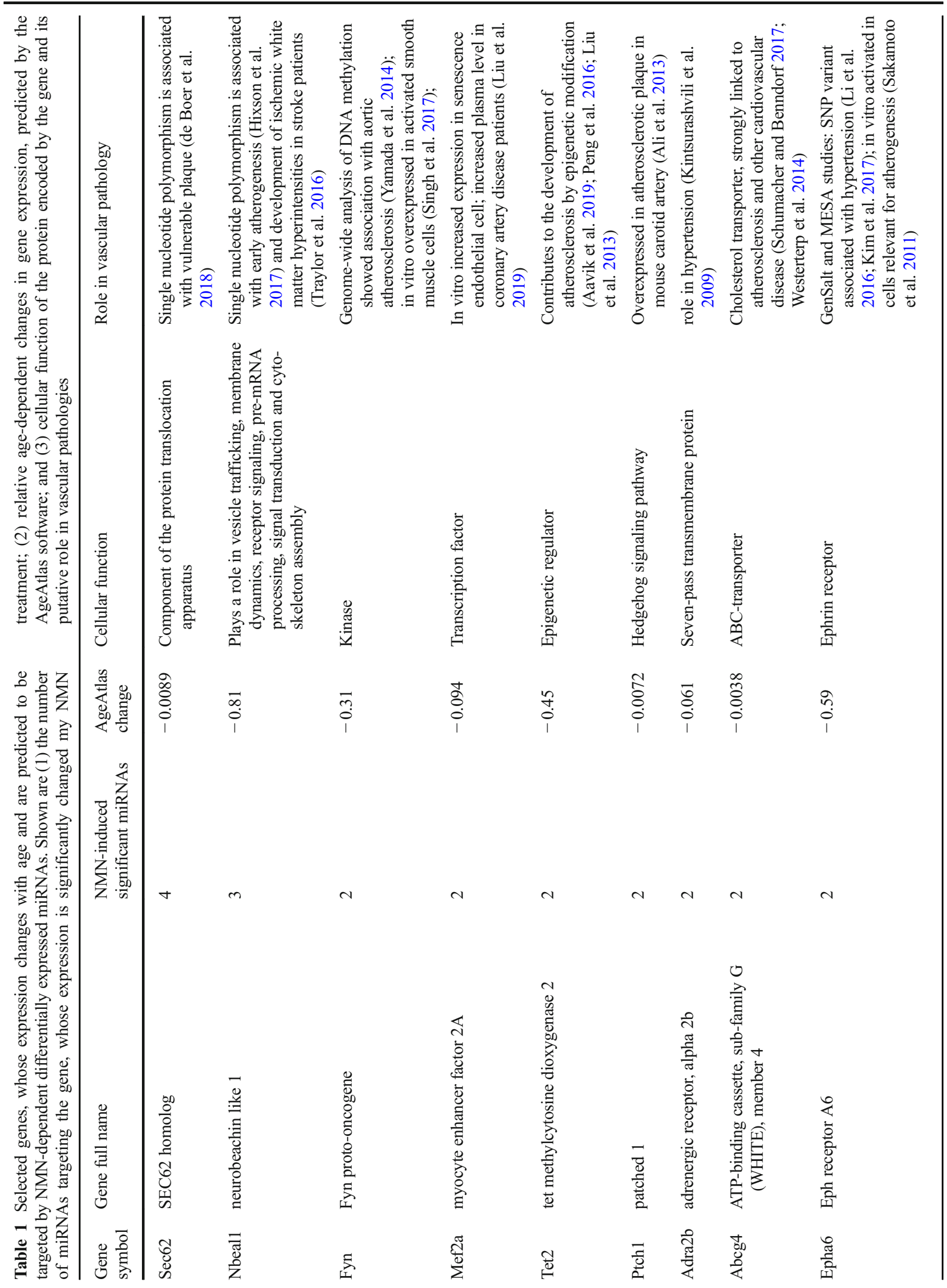


To our knowledge, this is the first study to demonstrate that NMN treatment in aged mice reverses, at least in part, age-related, pro-inflammatory, and pro-atherogenic alterations in miRNA expression profile in the aorta. These findings raise the possibility that changes in post-transcriptional control of expression of genes that encode critical targets for vascular health contribute to the beneficial effects of treatment with NAD+ boosters on health span. Demonstration of NMN-induced changes in miRNA biology in the vasculature is particularly important as alterations in miRNA expression profile have been causally linked to the development of cardiovascular aging phenotypes (Ungvari et al. 2013a; Boon et al. 2013; Csiszar et al. 2014) and the pathogenesis of cardiovascular diseases (Ono et al. 2011). A single miRNA can target up to several hundred mRNAs, thus capable of significantly altering gene expression regulatory networks. Systematic prediction of target pathways supports the concept that chronic NMN treatment may exert significant anti-atherogenic effects via epigenetic rejuvenation of the vasculature. These miRNA-mediated vasoprotective effects of NMN treatment appear to be synergistic with its endothelial protective, anti-aging, and pro-angiogenic effects demonstrated by recent studies (Tarantini et al. 2019; Csiszar et al. 2019; Kiss et al. 2019).

The molecular mechanisms contributing to aging-induced decline in $\mathrm{NAD}^{+}$in the vasculature are likely multifaceted and may include downr e g u lat i n of n i c ot i n a m i d e phosphoribosyltransferase (NAMPT, also known as NMN synthase; which catalyzes the rate limiting step in the biosynthesis of $\mathrm{NAD}^{+}$) (Tarantini et al. 2019) and increased utilization of $\mathrm{NAD}^{+}$by activated Poly [ADP-ribose] polymerase 1 (PARP1) (Csiszar et al. 2019; Pacher et al. 2002). Additional studies are warranted to determine the efficacy of combination treatments that simultaneously increase NAD+ production and inhibit its degradation (e.g., NMN plus a PARP-1 inhibitor) for the prevention of age-related vascular pathologies.

Previous studies demonstrate that restoration of $\mathrm{NAD}^{+}$levels by NMN treatment exert protective effects on endothelial vasodilation in aged rodents by reducing ROS generation and restoring mitochondrial function in a sirtuin-dependent manner (Tarantini et al. 2019). The mechanisms by which 
Table 2 Predicted regulatory effects of miRNAs whose expression is restored to youthful levels in aortas of aged mice by NMN supplementation. Shown are GO terms enriched among miRNAs differentially expressed with age in the aorta whose expression is significantly affected by NMN treatment. $N=$ genes in each GO category, targeted by miRNAs that are differentially regulated in the aged mouse aorta. Significance was determined by Fisher's exact test; odds ratio: (observed to expected ratio); SLPV: signed $\log 10 P$ value

\begin{tabular}{|c|c|c|c|c|}
\hline GO term ID & Name of biological process/molecular function & $\mathrm{N}$ & Odds Ratio & SLPV \\
\hline 6886 & Intracellular protein transport & 20 & 3.17 & 3.26 \\
\hline 7218 & Neuropeptide signaling pathway & 7 & 7.32 & 2.54 \\
\hline 5198 & Structural molecule activity & 6 & 9.40 & 2.45 \\
\hline 51082 & Unfolded protein binding & 7 & 5.49 & 2.20 \\
\hline 45778 & Positive regulation of ossification & 6 & 6.27 & 2.07 \\
\hline 50839 & Cell adhesion molecule binding & 10 & 3.49 & 1.92 \\
\hline 15137 & Citrate transmembrane transporter activity & 3 & $\inf$ & 1.84 \\
\hline 48227 & Plasma membrane to endosome transport & 3 & $\inf$ & 1.84 \\
\hline 8188 & Neuropeptide receptor activity & 3 & $\inf$ & 1.84 \\
\hline 7217 & Tachykinin receptor signaling pathway & 3 & inf & 1.84 \\
\hline 42594 & Response to starvation & 3 & $\inf$ & 1.84 \\
\hline 70536 & Protein K63-linked deubiquitination & 6 & 4.70 & 1.77 \\
\hline 71108 & Protein K48-linked deubiquitination & 6 & 4.70 & 1.77 \\
\hline 5102 & Receptor binding & 27 & 1.82 & 1.72 \\
\hline 90630 & Activation of GTPase activity & 10 & 2.85 & 1.71 \\
\hline 31338 & Regulation of vesicle fusion & 7 & 3.66 & 1.68 \\
\hline 1664 & G-protein coupled receptor binding & 6 & 3.76 & 1.52 \\
\hline 6631 & Fatty acid metabolic process & 6 & 3.76 & 1.52 \\
\hline 45777 & Positive regulation of blood pressure & 4 & 6.25 & 1.47 \\
\hline 32924 & Activin receptor signaling pathway & 4 & 6.25 & 1.47 \\
\hline 70530 & K63-linked polyubiquitin binding & 4 & 6.25 & 1.47 \\
\hline 10863 & Positive regulation of phospholipase $\mathrm{C}$ activity & 4 & 6.25 & 1.47 \\
\hline 16579 & Protein deubiquitination & 8 & 3.13 & 1.47 \\
\hline 18107 & Peptidyl-threonine phosphorylation & 9 & 2.57 & 1.42 \\
\hline 48015 & Phosphatidylinositol-mediated signaling & 5 & 3.91 & 1.36 \\
\hline 7200 & Phospholipase C-activating G-protein coupled receptor signaling pathway & 5 & 3.91 & 1.36 \\
\hline 71837 & HMG box domain binding & 5 & 3.91 & 1.36 \\
\hline 61578 & Lys63-specific deubiquitinase activity & 3 & 9.37 & 1.33 \\
\hline 33674 & Positive regulation of kinase activity & 3 & 9.37 & 1.33 \\
\hline 43122 & Regulation of I-kappaB kinase/NF-kappaB signaling & 3 & 9.37 & 1.33 \\
\hline 50995 & Negative regulation of lipid catabolic process & 3 & 9.37 & 1.33 \\
\hline
\end{tabular}

NAD+ boosters regulate miRNA expression are likely multifaceted and may include both transcriptional and post-transcriptional regulatory mechanisms (Fig. 3). NMN-induced transcriptional regulation may involve changes in the expression of miRNA genes due to altered transcription factor activity, changes in genome accessibility (e.g., histone modifications), and altered methylation status of the promoter of the miRNA genes. Post- transcriptional mechanisms affected by NMN treatment may include rescue of miRNA processing pathways (Ungvari et al. 2013b) and miRNA stability. Activation of sirtuins by NAD+ boosters, which has been linked to attenuation of age-related vascular oxidative stress (Tarantini et al. 2019; Kiss et al. 2019), may potentially contribute to both transcriptional and post-transcriptional regulation of miRNA expression in the vasculature. In particular, future 


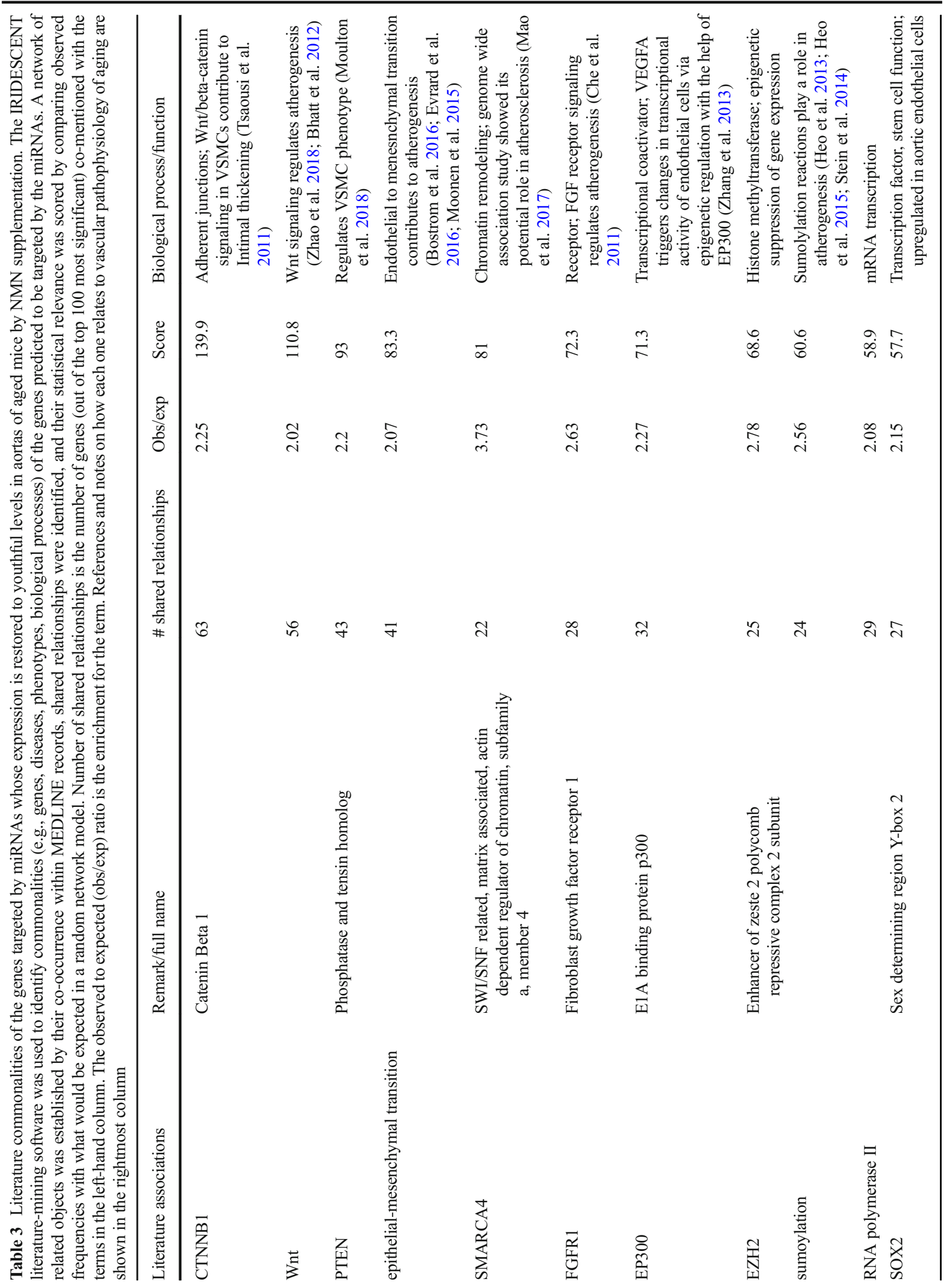




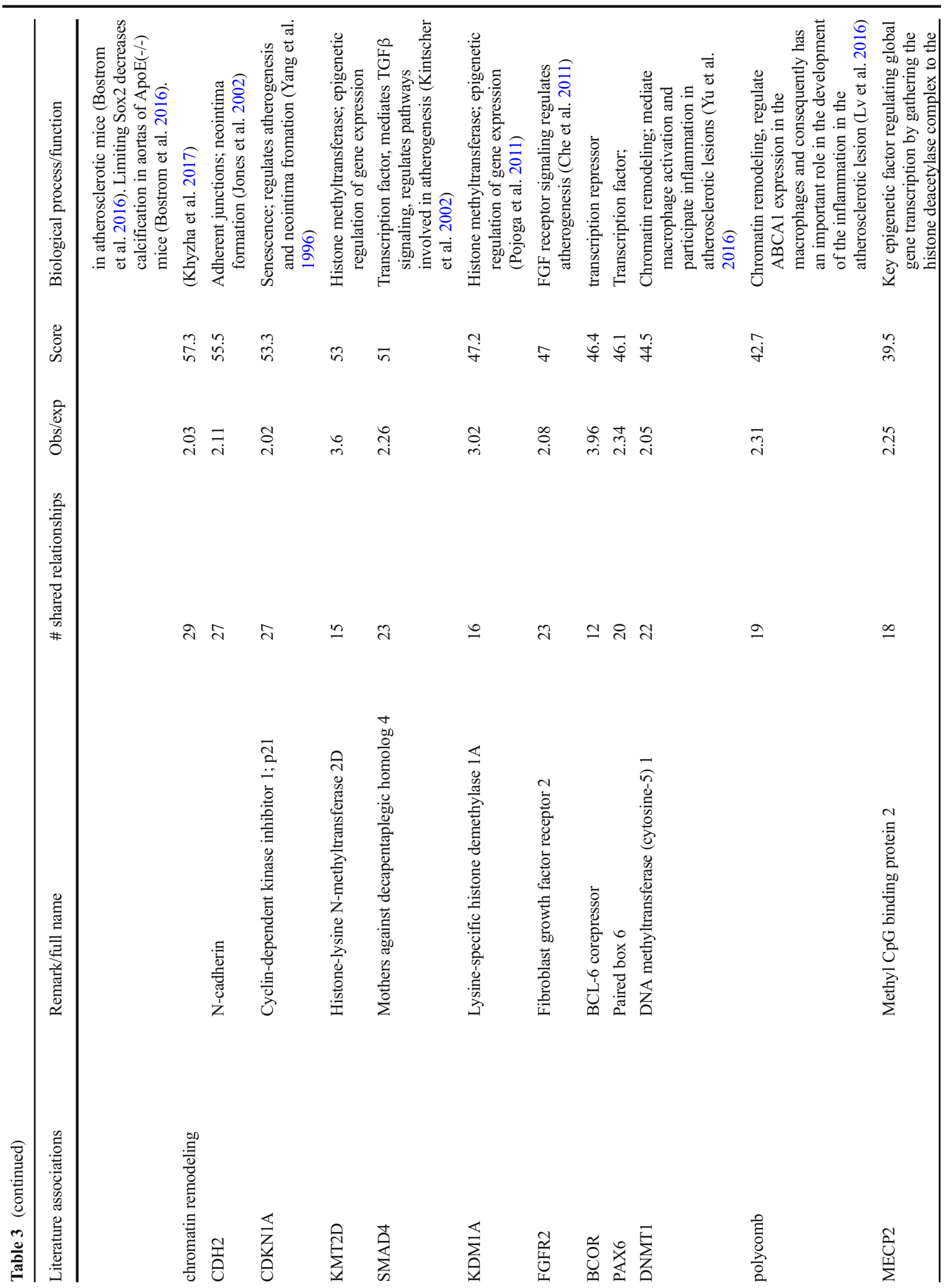




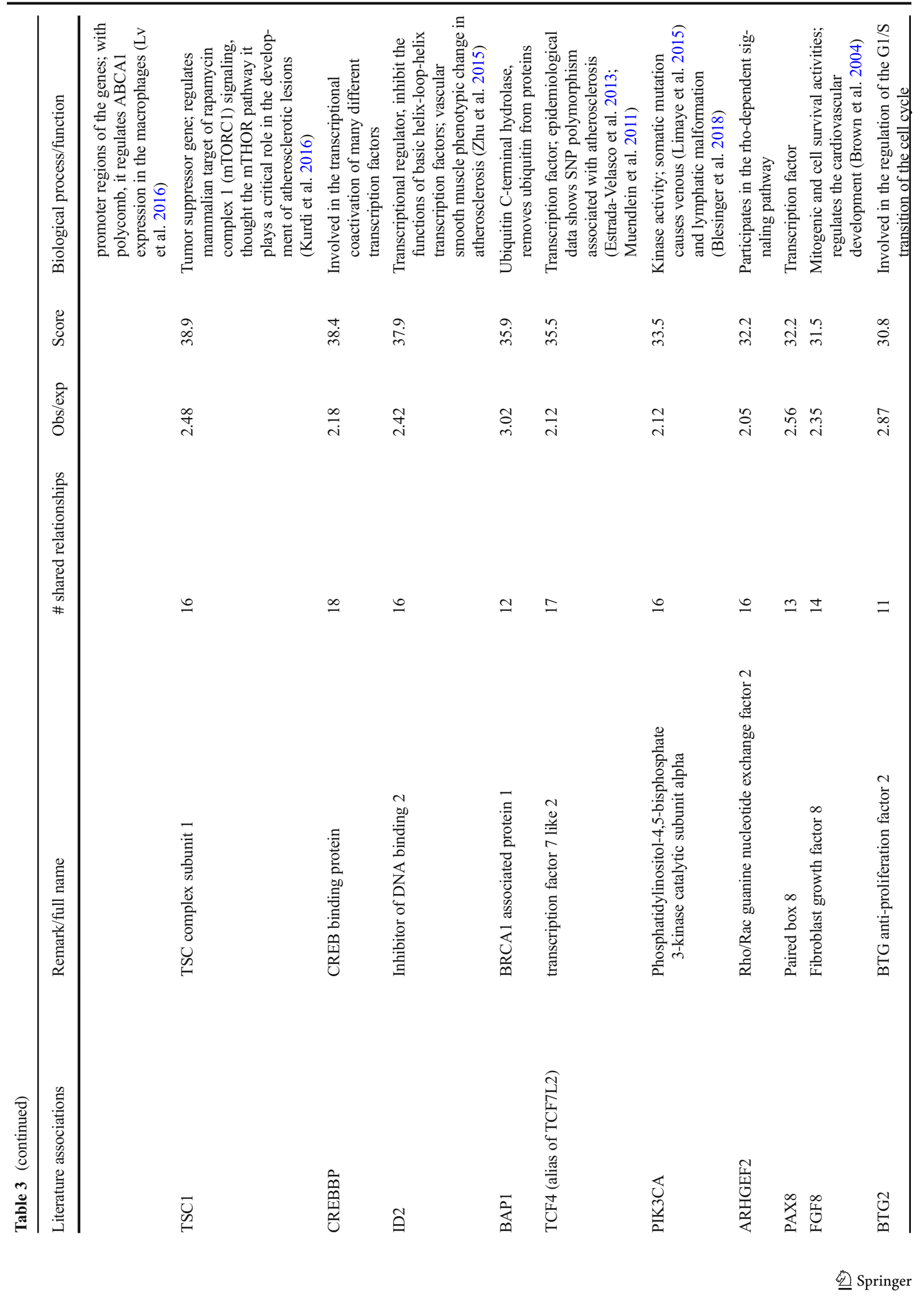




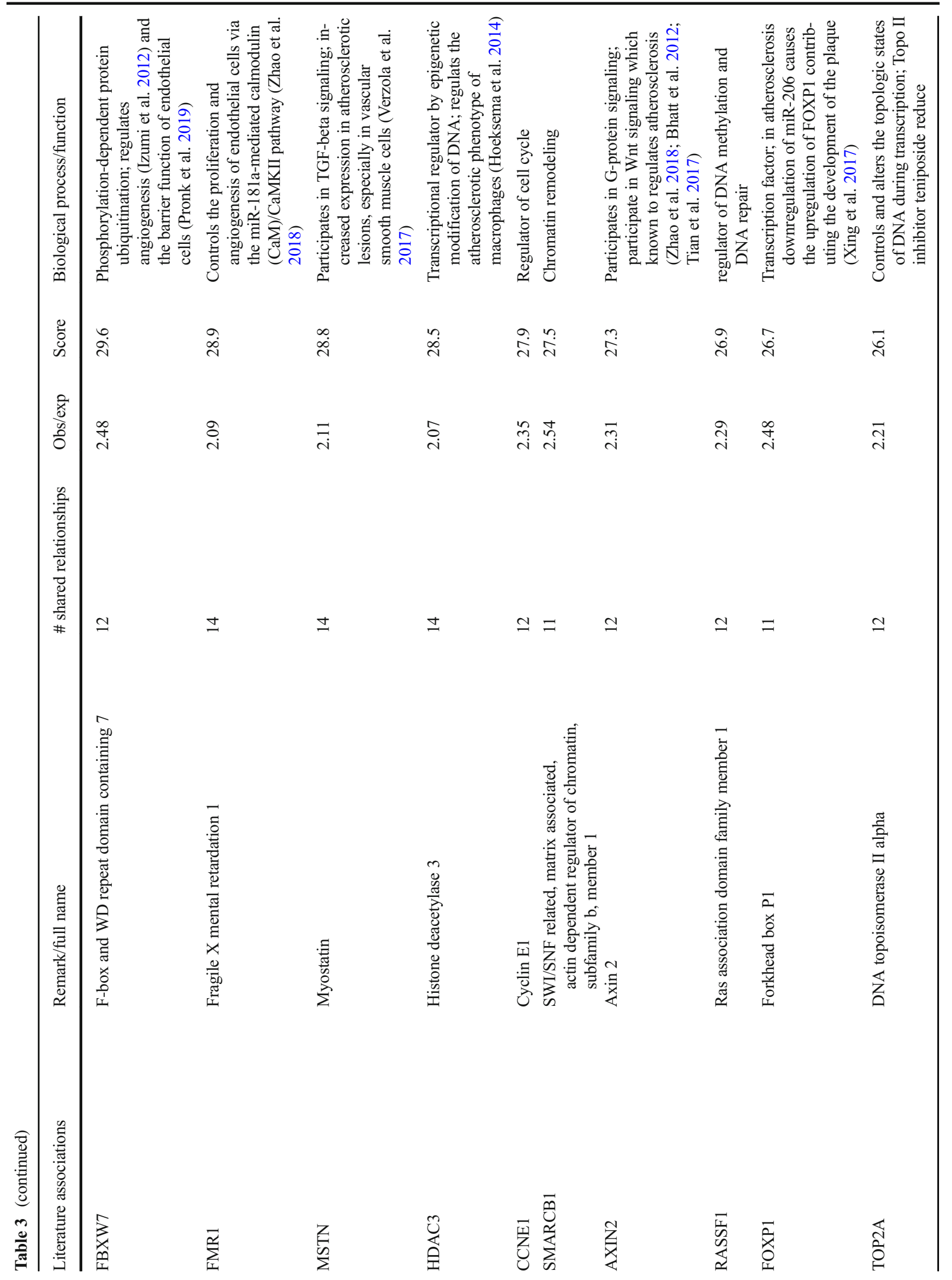


studies should determine how NMN treatment and sirtuin activation affect activity/expression of the Dicer/TRBP complex (Ungvari et al. 2013b). Further, the anti-aging vascular effects of caloric restriction also have been causally linked to sirtuin activation (Csiszar et al. 2009a). Importantly, caloric restriction also promotes significant anti-inflammatory and anti-atherogenic changes in vascular miRNA expression (Csiszar et al. 2014). Various humoral factors (e.g., hormones, cytokines) can also affect vascular miRNA expression. Additional studies are needed to determine the indirect effects of NMNinduced changes in humoral factors (e.g., adipokines) on vascular miRNA expression profile. The available evidence also supports the concept that a bi-directional link exists between NAD+ levels and miRNA expression (Choi et al. 2013). Recent studies identify the miR-34a/NAMPT (nicotinamide phosphoribosyltransferase) regulatory axis, which regulates SIRT1 activity through altering NAD+ levels (Choi et al. 2013). Interestingly, miR-34a tends to be increased in the aged mouse aorta $(\sim 2.9$-fold), which associates with a downregulation of NAMPT (Tarantini et al. 2019).

\section{Conclusions}

In conclusion, rescue of vascular function and attenuation of oxidative stress in the vasculature of NMN-treated aged mice is accompanied by antiaging changes in miRNA expression profile in the aorta. The predicted regulatory effects of NMNinduced differentially expressed miRNAs in aged vessels include anti-atherogenic affects and epigenetic rejuvenation (Fig. 3) and are consistent with the anti-aging functional effects of treatment with both NMN (Das et al. 2018; Tarantini et al. 2019; Kiss et al. 2019; de Picciotto et al. 2016) and sirtuin activators (Pearson et al. 2008; Csiszar et al. 2012; Mattison et al. 2014; Toth et al. 2015; Toth et al. 2014; Zhang et al. 2009; Oomen et al. 2009; Minor et al. 2011; Chen et al. 2015b; Gano et al. 2014) observed both in vivo and ex vivo. We hope that our findings will facilitate future endeavor of uncovering the mechanistic role of miRNA gene expression regulatory networks in the anti-aging effects of NAD+ booster treatments. Future studies should also investigate the links between miRNAs 


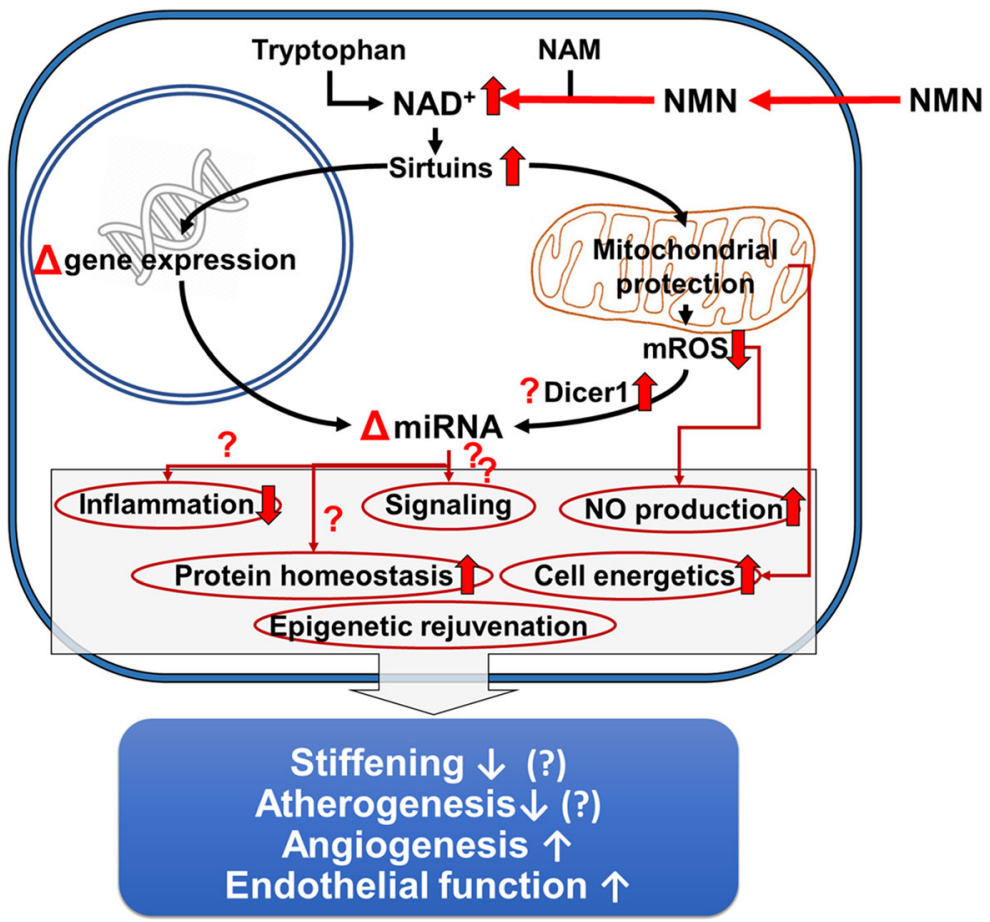

Fig. 3 Proposed scheme for the mechanisms by which restoration of NAD+ levels in the aged vasculature by NMN supplementation promotes anti-aging miRNA expression profile, rescues endothelial function, and prevents atherogenesis. The model, based on our present and previous findings and earlier data from the literature (Tarantini et al. 2019; Csiszar et al. 2019), predicts that increased NAD+ activates sirtuin-mediated pathways, restores cellular energetics and attenuates mitochondrial ROS (mtROS) production,

regulated by NMN and sirtuin activators and miRNAs known to act in the conserved pathways of aging (Ungvari et al. 2018; Menghini et al. 2014; Tarantini et al. 2016b; Kennedy et al. 2014; An et al. 2017; Ashpole et al. 2017; Bennis et al. 2017; Deepa et al. 2017; Fang et al. 2017; Fulop et al. 2018; Lee et al. 2018; Reglodi et al. 2018; Menghini et al. 2009; Fan et al. 2018) and major aging-related diseases (Csiszar et al. 2017; Meschiari et al. 2017; Tarantini et al. 2017b; Tucsek et al. 2017; Ungvari et al. 2017b; Carlson et al. 2018; Csipo et al. 2018; Tana et al. 2017; Feinberg and Moore 2016). Potentially, miRNA-regulated anti-aging mechanisms of $\mathrm{NAD}+$ booster treatments and sirtuin activators could be harnessed for development of new pharmacological approaches for the prevention and treatment of age-related vascular diseases.

Funding information This work was supported by grants from the American Heart Association (ST), the Oklahoma Center for the which lead to epigenetic changes promoting youthful gene/ miRNA expression, restore Dicer1-mediated miRNA processing, increase NO bioavailability, decrease inflammation, and improve protein homeostasis. All of these effects are predicted to act to decrease large artery stiffness, inhibit atherogenesis, improve vasodilation, and promote angiogenesis at the level of the microcirculation

Advancement of Science and Technology (to AC, AY, ZU), the National Institute on Aging (R01-AG047879; R01-AG038747; R01-AG055395), the National Institute of Neurological Disorders and Stroke (NINDS; R01-NS056218 to AC, R01-NS100782 to ZU), the Oklahoma Shared Clinical and Translational Resources (OSCTR) program funded by the National Institute of General Medical Sciences (GM104938, to AY and JW), the Presbyterian Health Foundation (to ZU, AC, AY), the NIA-supported Geroscience Training Program in Oklahoma (T32AG052363), the Oklahoma Nathan Shock Center (P30AG050911), and the Cellular and Molecular GeroScience CoBRE (1P20GM125528, sub\#5337). The funding sources had no role in the study design; in the collection, analysis, and interpretation of data; in the writing of the report; and in the decision to submit the article for publication.

\section{References}

Aavik E, Babu M, Yla-Herttuala S (2019) DNA methylation processes in atheosclerotic plaque. Atherosclerosis. 281: 168-179

Abdellatif M, Sedej S, Carmona-Gutierrez D, Madeo F, Kroemer G (2018) Autophagy in cardiovascular aging. Circ Res 123: 803-824 
Agarwal V, Bell GW, Nam JW, Bartel DP (2015) Predicting effective microRNA target sites in mammalian mRNAs. Elife. 4

Alfaras I, Di Germanio C, Bernier M, Csiszar A, Ungvari Z, Lakatta EG, de Cabo R (2016) Pharmacological strategies to retard cardiovascular aging. Circ Res 118:1626-1642

Ali H, Emoto N, Yagi K, Vignon-Zellweger N, Nakayama K, Hatakeyama K, Asada Y, Rikitake Y, Hirata K (2013) Localization and characterization of a novel secreted protein, SCUBE2, in the development and progression of atherosclerosis. Kobe J Med Sci 59:E122-E131

An JY, Quarles EK, Mekvanich S, Kang A, Liu A, Santos D, Miller RA, Rabinovitch PS, Cox TC and Kaeberlein M. Rapamycin treatment attenuates age-associated periodontitis in mice. Geroscience. 2017; https://doi.org/10.1007/s11357017-9994-6.

Anderson RM, Bitterman KJ, Wood JG, Medvedik O, Cohen H, Lin SS, Manchester JK, Gordon JI, Sinclair DA (2002) Manipulation of a nuclear NAD+ salvage pathway delays aging without altering steady-state NAD+ levels. J Biol Chem 277:18881-18890

Ashpole NM, Logan S, Yabluchanskiy A, Mitschelen MC, Yan H, Farley JA, Hodges EL, Ungvari Z, Csiszar A, Chen S, Georgescu C, Hubbard GB, Ikeno Y, Sonntag WE (2017) IGF-1 has sexually dimorphic, pleiotropic, and timedependent effects on healthspan, pathology, and lifespan. Geroscience. 39:129-145

Badi I, Mancinelli L, Polizzotto A, Ferri D, Zeni F, Burba I, Milano G, Brambilla F, Saccu C, Bianchi ME, Pompilio G, Capogrossi MC, Raucci A (2018) miR-34a Promotes vascular smooth muscle cell calcification by downregulating SIRT1 (Sirtuin 1) and Axl (AXL receptor tyrosine kinase). Arterioscler Thromb Vasc Biol 38:2079-2090

Bates DJ, Li N, Liang R, Sarojini H, An J, Masternak MM, Bartke A, Wang E MicroRNA regulation in Ames dwarf mouse liver may contribute to delayed aging. Aging Cell 9:1-18

Bennis MT, Schneider A, Victoria B, Do A, Wiesenborn DS, Spinel L, Gesing A, Kopchick JJ, Siddiqi SA, Masternak MM (2017) The role of transplanted visceral fat from the long-lived growth hormone receptor knockout mice on insulin signaling. Geroscience. 39:51-59

Bhatt PM, Lewis CJ, House DL, Keller CM, Kohn LD, Silver MJ, McCall KD, Goetz DJ, Malgor R (2012) Increased Wnt5a mRNA expression in advanced atherosclerotic lesions, and oxidized LDL treated human monocyte-derived macrophages. Open Circ Vasc J 5:1-7

Blesinger H, Kaulfuss S, Aung T, Schwoch S, Prantl L, Rossler J, Wilting J, Becker J (2018) PIK3CA mutations are specifically localized to lymphatic endothelial cells of lymphatic malformations. PLoS One 13:e0200343

Boehm M, Slack F (2005) A developmental timing microRNA and its target regulate life span in C. elegans. Science. 310: 1954-1957

de Boer S, Baran Y, Garcia-Garcia HM, Eskin I, Lenzen MJ, Kleber ME, Regar E, de Jaegere PJ, Ligthart JM, van Geuns RJ, Lehtimaki T, Laaksonen R, Boersma E, Marz W, Halperin E, Serruys PW, Koenig W (2018) The European collaborative project on inflammation and vascular wall remodeling in atherosclerosis - intravascular ultrasound (ATHEROREMO-IVUS) study. EuroIntervention. 14:194203
Bonauer A, Carmona G, Iwasaki M, Mione M, Koyanagi M, Fischer A, Burchfield J, Fox H, Doebele C, Ohtani K, Chavakis E, Potente M, Tjwa M, Urbich C, Zeiher AM, Dimmeler S (2009) MicroRNA-92a controls angiogenesis and functional recovery of ischemic tissues in mice. Science. 324:1710-1713

Boon RA, Iekushi K, Lechner S, Seeger T, Fischer A, Heydt S, Kaluza D, Treguer K, Carmona G, Bonauer A, Horrevoets AJ, Didier N, Girmatsion Z, Biliczki P, Ehrlich JR, Katus HA, Muller OJ, Potente M, Zeiher AM, Hermeking H, Dimmeler S (2013) MicroRNA-34a regulates cardiac ageing and function. Nature. 495:107-110

Bostrom KI, Yao J, Guihard PJ, Blazquez-Medela AM, Yao Y (2016) Endothelial-mesenchymal transition in atherosclerotic lesion calcification. Atherosclerosis. 253:124-127

Brown CB, Wenning JM, Lu MM, Epstein DJ, Meyers EN, Epstein JA (2004) Cre-mediated excision of Fgf8 in the Tbx1 expression domain reveals a critical role for Fgf8 in cardiovascular development in the mouse. Dev Biol 267: 190-202

Carlson BW, Craft MA, Carlson JR, Razaq W, Deardeuff KK, Benbrook DM (2018) Accelerated vascular aging and persistent cognitive impairment in older female breast cancer survivors. Geroscience. 40:325-336

Che J, Okigaki M, Takahashi T, Katsume A, Adachi Y, Yamaguchi S, Matsunaga S, Takeda M, Matsui A, Kishita E, Ikeda K, Yamada H, Matsubara H (2011) Endothelial FGF receptor signaling accelerates atherosclerosis. Am J Physiol Heart Circ Physiol 300:H154-H161

Che P, Liu J, Shan Z, Wu R, Yao C, Cui J, Zhu X, Wang J, Burnett MS, Wang S, Wang J (2014) miR-125a-5p impairs endothelial cell angiogenesis in aging mice via RTEF-1 downregulation. Aging Cell 13:926-934

Chen LJ, Chuang L, Huang YH, Zhou J, Lim SH, Lee CI, Lin WW, Lin TE, Wang WL, Chen L, Chien S, Chiu JJ (2015a) MicroRNA mediation of endothelial inflammatory response to smooth muscle cells and its inhibition by atheroprotective shear stress. Circ Res 116:1157-1169

Chen YX, Zhang M, Cai Y, Zhao Q, Dai W (2015b) The Sirt1 activator SRT1720 attenuates angiotensin II-induced atherosclerosis in apoE(-)/(-) mice through inhibiting vascular inflammatory response. Biochem Biophys Res Commun 465: $732-738$

Choi SE, Fu T, Seok S, Kim DH, Yu E, Lee KW, Kang Y, Li X, Kemper B, Kemper JK (2013) Elevated microRNA-34a in obesity reduces NAD+ levels and SIRT1 activity by directly targeting NAMPT. Aging Cell 12:1062-1072

Cox RH, Fromme SJ, Folander KL, Swanson RJ (2008) Voltage gated $\mathrm{K}+$ channel expression in arteries of Wistar-Kyoto and spontaneously hypertensive rats. Am J Hypertens 21:213218

Csipo T, Fulop GA, Lipecz A, Tarantini S, Kiss T, Balasubramanian P, Csiszar A (2018) Ungvari Z and Yabluchanskiy A. Short-term weight loss reverses obesityinduced microvascular endothelial dysfunction, Geroscience

Csiszar A, Labinskyy N, Podlutsky A, Kaminski PM, Wolin MS, Zhang C, Mukhopadhyay P, Pacher P, Hu F, de Cabo R, Ballabh P, Ungvari Z (2008) Vasoprotective effects of resveratrol and SIRT1: attenuation of cigarette smoke-induced oxidative stress and proinflammatory phenotypic alterations. Am J Physiol Heart Circ Physiol 294:H2721-H2735 
Csiszar A, Labinskyy N, Jimenez R, Pinto JT, Ballabh P, Losonczy G, Pearson KJ, de Cabo R, Ungvari Z (2009a) Anti-oxidative and anti-inflammatory vasoprotective effects of caloric restriction in aging: role of circulating factors and SIRT1. Mech Ageing Dev 130:518-527

Csiszar A, Labinskyy N, Pinto JT, Ballabh P, Zhang H, Losonczy G, Pearson KJ, de Cabo R, Pacher P, Zhang C, Ungvari ZI (2009b) Resveratrol induces mitochondrial biogenesis in endothelial cells. Am J Physiol Heart Circ Physiol

Csiszar A, Sosnowska D, Wang M, Lakatta EG, Sonntag WE, Ungvari Z (2012) Age-associated proinflammatory secretory phenotype in vascular smooth muscle cells from the nonhuman primate Macaca mulatta: reversal by resveratrol treatment. J Gerontol A Biol Sci Med Sci 67:811-820

Csiszar A, Gautam T, Sosnowska D, Tarantini S, Banki E, Tucsek Z, Toth P, Losonczy G, Koller A, Reglodi D, Giles CB, Wren JD, Sonntag WE, Ungvari Z (2014) Caloric restriction confers persistent anti-oxidative, pro-angiogenic, and antiinflammatory effects and promotes anti-aging miRNA expression profile in cerebromicrovascular endothelial cells of aged rats. Am J Physiol Heart Circ Physiol 307:H292-H306

Csiszar A, Tarantini S, Fulop GA, Kiss T, Valcarcel-Ares MN, Galvan V, Ungvari Z, Yabluchanskiy A (2017) Hypertension impairs neurovascular coupling and promotes microvascular injury: role in exacerbation of Alzheimer's disease. Geroscience.

Csiszar A, Tarantini S, Yabluchanskiy A, Balasubramanian P, Kiss T, Farkas E, Baur JA and Ungvari ZI (2019) Role of endothelial NAD+ deficiency in age-related vascular dysfunction. Am J Physiol Heart Circ Physiol:in press.

Das A, Huang GX, Bonkowski MS, Longchamp A, Li C, Schultz MB, Kim LJ, Osborne B, Joshi S, Lu Y, Trevino-Villarreal JH, Kang MJ, Hung TT, Lee B, Williams EO, Igarashi M, Mitchell JR, Wu LE, Turner N, Arany Z, Guarente L, Sinclair DA (2018) Impairment of an endothelial NAD(+)-H2S signaling network is a reversible cause of vascular aging. Cell. 173:74-89 e20

Deepa SS, Bhaskaran S, Espinoza S, Brooks SV, McArdle A, Jackson MJ, Van Remmen H, Richardson A (2017) A new mouse model of frailty: the $\mathrm{Cu} / \mathrm{Zn}$ superoxide dismutase knockout mouse. Geroscience. 39:187-198

Doebele C, Bonauer A, Fischer A, Scholz A, Reiss Y, Urbich C, Hofmann WK, Zeiher AM, Dimmeler S Members of the microRNA-17-92 cluster exhibit a cell intrinsic antiangiogenic function in endothelial cells. Blood.

ElSharawy A, Keller A, Flachsbart F, Wendschlag A, Jacobs G, Kefer N, Brefort T, Leidinger P, Backes C, Meese E, Schreiber S, Rosenstiel P, Franke A, Nebel A (2012) Genome-wide miRNA signatures of human longevity. Aging Cell 11:607-616

Estrada-Velasco BI, Cruz M, Madrid-Marina V, Martinez-Nava GA, Gomez-Zamudio J, Burguete-Garcia AI (2013) IRS1, TCF7L2, ADRB1, PPARG, and HHEX polymorphisms associated with atherogenic risk in Mexican population. Biomed Res Int 2013:394523

Evrard SM, Lecce L, Michelis KC, Nomura-Kitabayashi A, Pandey G, Purushothaman KR, d'Escamard V, Li JR, Hadri L, Fujitani K, Moreno PR, Benard L, Rimmele P, Cohain A, Mecham B, Randolph GJ, Nabel EG, Hajjar R, Fuster V, Boehm M, Kovacic JC (2016) Endothelial to mesenchymal transition is common in atherosclerotic lesions and is associated with plaque instability. Nat Commun 7:11853

Faccini J, Ruidavets JB, Cordelier P, Martins F, Maoret JJ, Bongard V, Ferrieres J, Roncalli J, Elbaz M, Vindis C (2017) Circulating miR-155, miR-145 and let-7c as diagnostic biomarkers of the coronary artery disease. Sci Rep 7: 42916

Fan B, Luk AOY, Chan JCN, Ma RCW (2018) MicroRNA and diabetic complications: a clinical perspective. Antioxid Redox Signal 29:1041-1063

Fang Y, McFadden S, Darcy J, Hill CM, Huber JA, Verhulst S, Kopchick JJ, Miller RA, Sun LY, Bartke A (2017) Differential effects of early-life nutrient restriction in longlived GHR-KO and normal mice. Geroscience. 39:347-356

Feinberg MW, Moore KJ (2016) MicroRNA regulation of atherosclerosis. Circ Res 118:703-720

Fulop GA, Kiss T, Tarantini S, Balasubramanian P, Yabluchanskiy A, Farkas E, Bari F, Ungvari Z, Csiszar A (2018) Nrf2 deficiency in aged mice exacerbates cellular senescence promoting cerebrovascular inflammation. Geroscience. 40:513521

Gano LB, Donato AJ, Pasha HM, Hearon CM Jr, Sindler AL, Seals DR (2014) The SIRT1 activator SRT1720 reverses vascular endothelial dysfunction, excessive superoxide production, and inflammation with aging in mice. Am J Physiol Heart Circ Physiol 307:H1754-H1763

Gomes AP, Price NL, Ling AJ, Moslehi JJ, Montgomery MK, Rajman L, White JP, Teodoro JS, Wrann CD, Hubbard BP, Mercken EM, Palmeira CM, de Cabo R, Rolo AP, Turner N, Bell EL, Sinclair DA (2013) Declining NAD(+) induces a pseudohypoxic state disrupting nuclear-mitochondrial communication during aging. Cell. 155:1624-1638

Grillari J, Grillari-Voglauer R Novel modulators of senescence, aging, and longevity: small non-coding RNAs enter the stage. Exp Gerontol 45:302-311

Guo Y, Li P, Gao L, Zhang J, Yang Z, Bledsoe G, Chang E, Chao L, Chao J (2017) Kallistatin reduces vascular senescence and aging by regulating microRNA-34a-SIRT1 pathway. Aging Cell 16:837-846

Harris MA, Clark J, Ireland A, Lomax J, Ashburner M, Foulger R, Eilbeck K, Lewis S, Marshall B, Mungall C, Richter J, Rubin GM, Blake JA, Bult C, Dolan M, Drabkin H, Eppig JT, Hill DP, Ni L, Ringwald M, Balakrishnan R, Cherry JM, Christie $\mathrm{KR}$, Costanzo MC, Dwight SS, Engel S, Fisk DG, Hirschman JE, Hong EL, Nash RS, Sethuraman A, Theesfeld CL, Botstein D, Dolinski K, Feierbach B, Berardini T, Mundodi S, Rhee SY, Apweiler R, Barrell D, Camon E, Dimmer E, Lee V, Chisholm R, Gaudet P, Kibbe W, Kishore R, Schwarz EM, Sternberg P, Gwinn M, Hannick L, Wortman J, Berriman M, Wood V, de la Cruz N, Tonellato P, Jaiswal P, Seigfried T, White R, Gene Ontology C (2004) The gene ontology (GO) database and informatics resource. Nucleic Acids Res 32:D258-D261

Hartmann P, Zhou Z, Natarelli L, Wei Y, Nazari-Jahantigh M, Zhu M, Grommes J, Steffens S, Weber C, Schober A (2016) Endothelial Dicer promotes atherosclerosis and vascular inflammation by miRNA-103-mediated suppression of KLF4. Nat Commun 7:10521

Hazra S, Henson GD, Morgan RG, Breevoort SR, Ives SJ, Richardson RS, Donato AJ, Lesniewski LA (2016) 
Experimental reduction of miR-92a mimics arterial aging. Exp Gerontol 83:165-170

Heo KS, Chang E, Le NT, Cushman H, Yeh ET, Fujiwara K, Abe J (2013) De-SUMOylation enzyme of sentrin/SUMO-specific protease 2 regulates disturbed flow-induced SUMOylation of ERK5 and p53 that leads to endothelial dysfunction and atherosclerosis. Circ Res 112:911-923

Heo KS, Le NT, Cushman HJ, Giancursio CJ, Chang E, Woo CH, Sullivan MA, Taunton J, Yeh ET, Fujiwara K, Abe J (2015) Disturbed flow-activated p90RSK kinase accelerates atherosclerosis by inhibiting SENP2 function. J Clin Invest 125: 1299-1310

Hergenreider E, Heydt S, Treguer K, Boettger T, Horrevoets AJ, Zeiher AM, Scheffer MP, Frangakis AS, Yin X, Mayr M, Braun T, Urbich C, Boon RA, Dimmeler S (2012) Atheroprotective communication between endothelial cells and smooth muscle cells through miRNAs. Nat Cell Biol 14: 249-256

Hixson JE, Jun G, Shimmin LC, Wang Y, Yu G, Mao C, Warren AS, Howard TD, Heide RSV, Van Eyk J, Wang Y, Herrington DM (2017) Whole exome sequencing to identify genetic variants associated with raised atherosclerotic lesions in young persons. Sci Rep 7:4091

Hoeksema MA, Gijbels MJ, Van den Bossche J, van der Velden S, Sijm A, Neele AE, Seijkens T, Stoger JL, Meiler S, Boshuizen MC, Dallinga-Thie GM, Levels JH, Boon L, Mullican SE, Spann NJ, Cleutjens JP, Glass CK, Lazar MA, de Vries CJ, Biessen EA, Daemen MJ, Lutgens E, de Winther MP (2014) Targeting macrophage Histone deacetylase 3 stabilizes atherosclerotic lesions. EMBO Mol Med 6:1124-1132

Hoenig MR, Bianchi C, Rosenzweig A, Sellke FW (2008) The cardiac microvasculature in hypertension, cardiac hypertrophy and diastolic heart failure. Curr Vasc Pharmacol 6:292300

Huang YQ, Cai AP, Chen JY, Huang C, Li J, Feng YQ (2016) The relationship of plasma miR-29a and oxidized low density lipoprotein with atherosclerosis. Cell Physiol Biochem 40: $1521-1528$

Ibanez-Ventoso C, Yang M, Guo S, Robins H, Padgett RW, Driscoll M (2006) Modulated microRNA expression during adult lifespan in Caenorhabditis elegans. Aging Cell 5:235246

Inukai S, Slack F (2013) MicroRNAs and the genetic network in aging. J Mol Biol

Inukai S, de Lencastre A, Turner M, Slack F (2012) Novel microRNAs differentially expressed during aging in the mouse brain. PLoS One 7:e40028

Ito T, Yagi S, Yamakuchi M (2010) MicroRNA-34a regulation of endothelial senescence. Biochem Biophys Res Commun 398:735-740

Izumi N, Helker C, Ehling M, Behrens A, Herzog W, Adams RH (2012) Fbxw7 controls angiogenesis by regulating endothelial Notch activity. PLoS One 7:e41116

Jansen F, Yang X, Nickenig G, Werner N, Vasa-Nicotera M (2015) Role, function and therapeutic potential of microRNAs in vascular aging. Curr Vasc Pharmacol 13:324-330

Jones M, Sabatini PJ, Lee FS, Bendeck MP, Langille BL (2002) Ncadherin upregulation and function in response of smooth muscle cells to arterial injury. Arterioscler Thromb Vasc Biol 22:1972-1977
Kennedy BK, Berger SL, Brunet A, Campisi J, Cuervo AM, Epel ES, Franceschi C, Lithgow GJ, Morimoto RI, Pessin JE, Rando TA, Richardson A, Schadt EE, Wyss-Coray T, Sierra F (2014) Geroscience: linking aging to chronic disease. Cell. 159:709-713

Khyzha N, Alizada A, Wilson MD, Fish JE (2017) Epigenetics of atherosclerosis: emerging mechanisms and methods. Trends Mol Med 23:332-347

Kim CW, Kumar S, Son DJ, Jang IH, Griendling KK, Jo H (2014) Prevention of abdominal aortic aneurysm by antimicroRNA-712 or anti-microRNA-205 in angiotensin IIinfused mice. Arterioscler Thromb Vasc Biol 34:1412-1421

Kim M, Yoo HJ, Kim M, Kim J, Baek SH, Song M, Lee JH (2017) EPHA6 rs4857055 $\mathrm{C}>\mathrm{T}$ polymorphism associates with hypertension through triglyceride and LDL particle size in the Korean population. Lipids Health Dis 16:230

Kintscher U, Lyon C, Wakino S, Bruemmer D, Feng X, Goetze S, Graf K, Moustakas A, Staels B, Fleck E, Hsueh WA, Law RE (2002) PPARalpha inhibits TGF-beta-induced beta5 integrin transcription in vascular smooth muscle cells by interacting with Smad4. Circ Res 91:e35-e44

Kintsurashvili E, Shenouda S, Ona D, Ona L, Ahmad S, Ravid K, Gavras I, Gavras H (2009) Hypertension in transgenic mice with brain-selective overexpression of the alpha(2B)adrenoceptor. Am J Hypertens 22:41-45

Kisler K, Nelson AR, Montagne A, Zlokovic BV (2017) Cerebral blood flow regulation and neurovascular dysfunction in Alzheimer disease. Nat Rev Neurosci 18:419-434

Kiss T, Balasubramanian P, Valcarcel-Ares MN, Tarantini S, Yabluchanskiy A, Csipo T, Lipecz A, Reglodi D, Zhang XA, Bari F, Farkas E, Csiszar A and Ungvari Z (2019) Nicotinamide mononucleotide (NMN) treatment attenuates oxidative stress and rescues angiogenic capacity in aged cerebromicrovascular endothelial cells: a potential mechanism for prevention of vascular cognitive impairment. GeroScience.:in press.

Kuehbacher A, Urbich C, Zeiher AM, Dimmeler S (2007) Role of Dicer and Drosha for endothelial microRNA expression and angiogenesis. Circ Res 101:59-68

Kurdi A, De Meyer GR, Martinet W (2016) Potential therapeutic effects of mTOR inhibition in atherosclerosis. Br J Clin Pharmacol 82:1267-1279

Lee HJ, Feliers D, Barnes JL, Oh S, Choudhury GG, Diaz V, Galvan V, Strong R, Nelson J, Salmon A, Kevil CG, Kasinath BS (2018) Hydrogen sulfide ameliorates aging-associated changes in the kidney. Geroscience. 40:163-176

Leung A, Trac C, Jin W, Lanting L, Akbany A, Saetrom P, Schones DE, Natarajan R (2013) Novel long noncoding RNAs are regulated by angiotensin II in vascular smooth muscle cells. Circ Res 113:266-278

Li C, He J, Chen J, Zhao J, Gu D, Hixson JE, Rao DC, Jaquish CE, Gu CC, Chen J, Huang J, Chen S, Kelly TN (2016) Genomewide gene-sodium interaction analyses on blood pressure: the genetic epidemiology network of salt-sensitivity study. Hypertension. 68:348-355

Limaye N, Kangas J, Mendola A, Godfraind C, Schlogel MJ, Helaers R, Eklund L, Boon LM, Vikkula M (2015) Somatic activating PIK3CA mutations cause venous malformation. Am J Hum Genet 97:914-921

Liu R, Jin Y, Tang WH, Qin L, Zhang X, Tellides G, Hwa J, Yu J, Martin KA (2013) Ten-eleven translocation-2 (TET2) is a 
master regulator of smooth muscle cell plasticity. Circulation. 128:2047-2057

Liu L, Zeng P, Yang X, Duan Y, Zhang W, Ma C, Zhang X, Yang S, Li X, Yang J, Liang Y, Han H, Zhu Y, Han J, Chen Y (2018) Inhibition of vascular calcification. Arterioscler Thromb Vasc Biol 38:2382-2395

Liu B, Wang L, Jiang W, Xiong Y, Pang L, Zhong Y, Zhang C, Ou W, Tian C, Chen X and Liu SM (2019) Myocyte enhancer factor 2A delays vascular endothelial cell senescence by activating the PI3K/p-Akt/SIRT1 pathway. Aging (Albany $N Y)$..

Livak KJ, Schmittgen TD (2001) Analysis of relative gene expression data using real-time quantitative PCR and the 2(-Delta Delta C(T)) Method. Methods. 25:402-408

Long DA, Norman JT, Fine LG (2012) Restoring the renal microvasculature to treat chronic kidney disease. Nat Rev Nephrol $8: 244-250$

Lopez-Mejias R, Genre F, Remuzgo-Martinez S, GonzalezJuanatey C, Robustillo-Villarino M, Llorca J, Corrales A, Vicente E, Miranda-Filloy JA, Magro C, Tejera-Segura B, Ramirez Huaranga MA, Pina T, Blanco R, Alegre-Sancho JJ, Raya E, Mijares V, Ubilla B, Minguez Sanchez MD, GomezVaquero C, Balsa A, Pascual-Salcedo D, Lopez-Longo FJ, Carreira P, Gonzalez-Alvaro I, Rodriguez-Rodriguez L, Fernandez-Gutierrez B, Ferraz-Amaro I, Castaneda S, Martin J, Gonzalez-Gay MA (2016) Influence of elevatedCRP level-related polymorphisms in non-rheumatic Caucasians on the risk of subclinical atherosclerosis and cardiovascular disease in rheumatoid arthritis. Sci Rep 6: 31979

Lovren F, Pan Y, Quan A, Singh KK, Shukla PC, Gupta N, Steer BM, Ingram AJ, Gupta M, Al-Omran M, Teoh H, Marsden PA, Verma S (2012) MicroRNA-145 targeted therapy reduces atherosclerosis. Circulation. 126:S81-S90

Lu Y, Thavarajah T, Gu W, Cai J, Xu Q (2018) Impact of miRNA in atherosclerosis. Arterioscler Thromb Vasc Biol 38:e159e170

Lv YC, Tang YY, Zhang P, Wan W, Yao F, He PP, Xie W, Mo ZC, Shi JF, Wu JF, Peng J, Liu D, Cayabyab FS, Zheng XL, Tang XY, Ouyang XP, Tang CK (2016) Histone methyltransferase enhancer of zeste homolog 2-mediated ABCA1 promoter DNA methylation contributes to the progression of atherosclerosis. PLoS One 11:e0157265

Maes OC, An J, Sarojini H, Wang E (2008) Murine microRNAs implicated in liver functions and aging process. Mech Ageing Dev 129:534-541

Mao C, Howard TD, Sullivan D, Fu Z, Yu G, Parker SJ, Will R, Vander Heide RS, Wang Y, Hixson J, Van Eyk J, Herrington DM (2017) Bioinformatic analysis of coronary disease associated SNPs and genes to identify proteins potentially involved in the pathogenesis of atherosclerosis. J Proteom Genom Res 2:1-12

Mao Z, Wu F, Shan Y (2018) Identification of key genes and miRNAs associated with carotid atherosclerosis based on mRNA-seq data. Medicine (Baltimore) 97:e9832

Massudi H, Grant R, Braidy N, Guest J, Farnsworth B, Guillemin GJ (2012) Age-associated changes in oxidative stress and NAD+ metabolism in human tissue. PLoS One 7:e42357

Mattison JA, Wang M, Bernier M, Zhang J, Park SS, Maudsley S, An SS, Santhanam L, Martin B, Faulkner S, Morrell C, Baur JA, Peshkin L, Sosnowska D, Csiszar A, Herbert RL,
Tilmont EM, Ungvari Z, Pearson KJ, Lakatta EG, de Cabo R (2014) Resveratrol prevents high fat/sucrose diet-induced central arterial wall inflammation and stiffening in nonhuman primates. Cell Metab 20:183-190

Menghini R, Casagrande V, Cardellini M, Martelli E, Terrinoni A, Amati F, Vasa-Nicotera M, Ippoliti A, Novelli G, Melino G, Lauro R, Federici M (2009) MicroRNA 217 modulates endothelial cell senescence via silent information regulator 1 . Circulation. 120:1524-1532

Menghini R, Stohr R, Federici M (2014) MicroRNAs in vascular aging and atherosclerosis. Ageing Res Rev 17:68-78

Mercken EM, Majounie E, Ding J, Guo R, Kim J, Bernier M, Mattison J, Cookson MR, Gorospe M, de Cabo R, Abdelmohsen K (2013) Age-associated miRNA alterations in skeletal muscle from rhesus monkeys reversed by caloric restriction. Aging (Albany NY) 5:692-703

Meschiari CA, Ero OK, Pan H, Finkel T, Lindsey ML (2017) The impact of aging on cardiac extracellular matrix. Geroscience. 39:7-18

Minamino T, Komuro I (2007) Vascular cell senescence: contribution to atherosclerosis. Circ Res 100:15-26

Minor RK, Baur JA, Gomes AP, Ward TM, Csiszar A, Mercken EM, Abdelmohsen K, Shin YK, Canto C, Scheibye-Knudsen M, Krawczyk M, Irusta PM, Martin-Montalvo A, Hubbard BP, Zhang Y, Lehrmann E, White AA, Price NL, Swindell WR, Pearson KJ, Becker KG, Bohr VA, Gorospe M, Egan JM, Talan MI, Auwerx J, Westphal CH, Ellis JL, Ungvari Z, Vlasuk GP, Elliott PJ, Sinclair DA, de Cabo R (2011) SRT1720 improves survival and healthspan of obese mice. Sci Rep 1. https://doi.org/10.1038/srep00070

Mitchell SJ, Bernier M, Aon MA, Cortassa S, Kim EY, Fang EF, Palacios HH, Ali A, Navas-Enamorado I, Di Francesco A, Kaiser TA, Waltz TB, Zhang N, Ellis JL, Elliott PJ, Frederick DW, Bohr VA, Schmidt MS, Brenner C, Sinclair DA, Sauve AA, Baur JA, de Cabo R (2018) Nicotinamide improves aspects of healthspan, but not lifespan, in mice. Cell Metab 27:667-676 e4

Montagne A, Zhao Z, Zlokovic BV (2017) Alzheimer's disease: a matter of blood-brain barrier dysfunction? J Exp Med 214: 3151-3169

Moonen JR, Lee ES, Schmidt M, Maleszewska M, Koerts JA, Brouwer LA, van Kooten TG, van Luyn MJ, Zeebregts CJ, Krenning G, Harmsen MC (2015) Endothelial-tomesenchymal transition contributes to fibro-proliferative vascular disease and is modulated by fluid shear stress. Cardiovasc Res 108:377-386

Moulton KS, Li M, Strand K, Burgett S, McClatchey P, Tucker R, Furgeson SB, Lu S, Kirkpatrick B, Cleveland JC, Nemenoff RA, Ambardekar AV, Weiser-Evans MC (2018) PTEN deficiency promotes pathological vascular remodeling of human coronary arteries. JCI Insight 3

Muendlein A, Saely CH, Geller-Rhomberg S, Sonderegger G, Rein P, Winder T, Beer S, Vonbank A, Drexel H (2011) Single nucleotide polymorphisms of TCF7L2 are linked to diabetic coronary atherosclerosis. PLoS One 6:e17978

Mullins RF, Khanna A, Schoo DP, Tucker BA, Sohn EH, Drack $\mathrm{AV}$, Stone EM (2014) Is age-related macular degeneration a microvascular disease? Adv Exp Med Biol 801:283-289

O'Rourke JR, Olson EN (2011) Modulating the MicroRNArchitecture of an aging aorta. Circ Res 109: 1098-1099 
Ohukainen P, Syvaranta S, Napankangas J, Rajamaki K, Taskinen P, Peltonen T, Helske-Suihko S, Kovanen PT, Ruskoaho H, Rysa J (2015) MicroRNA-125b and chemokine CCL4 expression are associated with calcific aortic valve disease. Ann Med 47:423-429

Ono K, Kuwabara Y, Han J (2011) MicroRNAs and cardiovascular diseases. FEBS J 278:1619-1633

Oomen CA, Farkas E, Roman V, van der Beek EM, Luiten PG, Meerlo P (2009) Resveratrol preserves cerebrovascular density and cognitive function in aging mice. Front Aging Neurosci 1:4

Pacher P, Mabley JG, Soriano FG, Liaudet L, Komjati K, Szabo C (2002) Endothelial dysfunction in aging animals: the role of poly(ADP-ribose) polymerase activation. Br J Pharmacol 135:1347-1350

Payne GW (2006) Effect of inflammation on the aging microcirculation: impact on skeletal muscle blood flow control. Microcirculation. 13:343-352

Pearson KJ, Baur JA, Lewis KN, Peshkin L, Price NL, Labinskyy N, Swindell WR, Kamara D, Minor RK, Perez E, Jamieson HA, Zhang Y, Dunn SR, Sharma K, Pleshko N, Woollett LA, Csiszar A, Ikeno Y, Le Couteur D, Elliott PJ, Becker KG, Navas P, Ingram DK, Wolf NS, Ungvari Z, Sinclair DA, de Cabo R (2008) Resveratrol delays age-related deterioration and mimics transcriptional aspects of dietary restriction without extending life span. Cell Metab 8:157-168

Peng J, Yang Q, Li AF, Li RQ, Wang Z, Liu LS, Ren Z, Zheng XL, Tang XQ, Li GH, Tang ZH, Jiang ZS, Wei DH (2016) Tet methylcytosine dioxygenase 2 inhibits atherosclerosis via upregulation of autophagy in ApoE-/- mice. Oncotarget. 7: 76423-76436

de Picciotto NE, Gano LB, Johnson LC, Martens CR, Sindler AL, Mills KF, Imai S, Seals DR (2016) Nicotinamide mononucleotide supplementation reverses vascular dysfunction and oxidative stress with aging in mice. Aging Cell 15:522-530

Pilbrow AP, Cordeddu L, Cameron VA, Frampton CM, Troughton RW, Doughty RN, Whalley GA, Ellis CJ, Yandle TG, Richards AM, Foo RS (2014) Circulating miR-323-3p and miR-652: candidate markers for the presence and progression of acute coronary syndromes. Int J Cardiol 176:375-385

Pojoga LH, Williams JS, Yao TM, Kumar A, Raffetto JD, do Nascimento GR, Reslan OM, Adler GK, Williams GH, Shi Y, Khalil RA (2011) Histone demethylase LSD1 deficiency during high-salt diet is associated with enhanced vascular contraction, altered NO-cGMP relaxation pathway, and hypertension. Am J Physiol Heart Circ Physiol 301:H1862H1871

Pronk MCA, Majolee J, Loregger A, van Bezu JSM, Zelcer N, Hordijk PL, Kovacevic I (2019) FBXW7 regulates endothelial barrier function by suppression of the cholesterol synthesis pathway and prenylation of RhoB. Mol Biol Cell 30:607621

Raghavan S, Singh NK, Gali S, Mani AM, Rao GN (2018) Protein kinase Ctheta via activating transcription factor 2-mediated CD36 expression and foam cell formation of Ly6C(hi) cells contributes to atherosclerosis. Circulation. 138:2395-2412

Regina C, Panatta E, Candi E, Melino G, Amelio I, Balistreri CR, Annicchiarico-Petruzzelli M, Di Daniele N, Ruvolo G (2016) Vascular ageing and endothelial cell senescence: Molecular mechanisms of physiology and diseases. Mech Ageing Dev 159:14-21
Reglodi D, Atlasz T, Szabo E, Jungling A, Tamas A, Juhasz T, Fulop BD, Bardosi A (2018) PACAP deficiency as a model of aging. Geroscience. 40:437-452

Rippe C, Zhu B, Krawczyk KK, Bavel EV, Albinsson S, Sjolund J, Bakker E, Sward K (2017) Hypertension reduces soluble guanylyl cyclase expression in the mouse aorta via the Notch signaling pathway. Sci Rep 7:1334

Rotllan N, Ramirez CM, Aryal B, Esau CC, Fernandez-Hernando C (2013) Therapeutic silencing of microRNA-33 inhibits the progression of atherosclerosis in Ldlr-/- mice-brief report. Arterioscler Thromb Vasc Biol 33:1973-1977

Sagare AP, Bell RD, Zlokovic BV (2013) Neurovascular defects and faulty amyloid-beta vascular clearance in Alzheimer's disease. J Alzheimers Dis 33(Suppl 1):S87-S100

Sakamoto A, Sugamoto Y, Tokunaga Y, Yoshimuta T, Hayashi K, Konno T, Kawashiri MA, Takeda Y, Yamagishi M (2011) Expression profiling of the ephrin (EFN) and Eph receptor (EPH) family of genes in atherosclerosis-related human cells. J Int Med Res 39:522-527

Schumacher T, Benndorf RA (2017) ABC transport proteins in cardiovascular disease-a brief summary. Molecules. 22

Signorelli SS, Volsi GL, Pitruzzella A, Fiore V, Mangiafico M, Vanella L, Parenti R, Rizzo M, Volti GL (2016) Circulating miR-130a, miR-27b, and miR-210 in patients with peripheral artery disease and their potential relationship with oxidative stress. Angiology. 67:945-950

Singh NK, Janjanam J, Rao GN (2017) p115 RhoGEF activates the Rac1 GTPase signaling cascade in MCP1 chemokineinduced vascular smooth muscle cell migration and proliferation. J Biol Chem 292:14080-14091

Smith-Vikos T, Slack FJ (2012) MicroRNAs and their roles in aging. J Cell Sci 125:7-17

Smith-Vikos T, Liu Z, Parsons C, Gorospe M, Ferrucci L, Gill TM, Slack FJ (2016) A serum miRNA profile of human longevity: findings from the Baltimore Longitudinal Study of Aging (BLSA). Aging (Albany NY) 8:2971-2987

Stein S, Oosterveer MH, Mataki C, Xu P, Lemos V, Havinga R, Dittner C, Ryu D, Menzies KJ, Wang X, Perino A, Houten SM, Melchior F, Schoonjans K (2014) SUMOylationdependent LRH-1/PROX1 interaction promotes atherosclerosis by decreasing hepatic reverse cholesterol transport. Cell Metab 20:603-613

Stellos K, Dimmeler S (2014) Vascular microRNAs: from disease mechanisms to therapeutic targets. Circ Res 114:3-4

Sullivan I, Riera P, Andres M, Altes A, Majem M, Blanco R, Capdevila L, Barba A, Barnadas A and Salazar J (2019) Prognostic effect of VEGF gene variants in metastatic nonsmall-cell lung cancer patients. Angiogenesis.

Sweeney MD, Kisler K, Montagne A, Toga AW, Zlokovic BV (2018) The role of brain vasculature in neurodegenerative disorders. Nat Neurosci 21:1318-1331

Tana C, Giamberardino MA, Cipollone F (2017) microRNA profiling in atherosclerosis, diabetes, and migraine. Ann Med 49: 93-105

Tarantini S, Tran CH, Gordon GR, Ungvari Z, Csiszar A (2016a) Impaired neurovascular coupling in aging and Alzheimer's disease: contribution of astrocyte dysfunction and endothelial impairment to cognitive decline. Exp Gerontol 94. https://doi.org/10.1016/j.exger.2016.11.004

Tarantini S, Giles CB, Wren JD, Ashpole NM, Valcarcel-Ares MN, Wei JY, Sonntag WE, Ungvari Z, Csiszar A (2016b) 
IGF-1 deficiency in a critical period early in life influences the vascular aging phenotype in mice by altering miRNAmediated post-transcriptional gene regulation: implications for the developmental origins of health and disease hypothesis. Age (Dordr) 38:239-258

Tarantini S, Tran CHT, Gordon GR, Ungvari Z, Csiszar A (2017a) Impaired neurovascular coupling in aging and Alzheimer's disease: contribution of astrocyte dysfunction and endothelial impairment to cognitive decline. Exp Gerontol 94:52-58

Tarantini S, Fulop GA, Kiss T, Farkas E, Zolei-Szenasi D, Galvan V, Toth P, Csiszar A, Ungvari Z, Yabluchanskiy A (2017b) Demonstration of impaired neurovascular coupling responses in TG2576 mouse model of Alzheimer's disease using functional laser speckle contrast imaging. Geroscience.

Tarantini S, Valcarcel-Ares MN, Toth P, Yabluchanskiy A, Tucsek Z, Kiss T, Hertelendy P, Kinter M, Ballabh P, Sule Z, Farkas E, Baur JA, Sinclair DA, Csiszar A, Ungvari Z (2019) Nicotinamide mononucleotide (NMN) supplementation rescues cerebromicrovascular endothelial function and neurovascular coupling responses and improves cognitive function in aged mice. Redox Biol 24:101192

Tian L, Chen K, Cao J, Han Z, Wang Y, Gao L, Fan Y, Wang C (2017) Galectin3 induces the phenotype transformation of human vascular smooth muscle cells via the canonical Wnt signaling. Mol Med Rep 15:3840-3846

Toth P, Tarantini S, Tucsek Z, Ashpole NM, Sosnowska D, Gautam T, Ballabh P, Koller A, Sonntag WE, Csiszar A, Ungvari ZI (2014) Resveratrol treatment rescues neurovascular coupling in aged mice:role of improved cerebromicrovascular endothelial function and downregulation of NADPH oxidas. Am J Physiol Heart Circ Physiol 306:H299-H308

Toth P, Tarantini S, Springo Z, Tucsek Z, Gautam T, Giles CB, Wren JD, Koller A, Sonntag WE, Csiszar A, Ungvari Z (2015) Aging exacerbates hypertension-induced cerebral microhemorrhages in mice: role of resveratrol treatment in vasoprotection. Aging Cell 14:400-408

Toth P, Tarantini S, Csiszar A, Ungvari Z (2017) Functional vascular contributions to cognitive impairment and dementia: mechanisms and consequences of cerebral autoregulatory dysfunction, endothelial impairment, and neurovascular uncoupling in aging. Am J Physiol Heart Circ Physiol 312: $\mathrm{H} 1-\mathrm{H} 20$

Traylor M, Zhang CR, Adib-Samii P, Devan WJ, Parsons OE, Lanfranconi S, Gregory S, Cloonan L, Falcone GJ, Radmanesh F, Fitzpatrick K, Kanakis A, Barrick TR, Moynihan B, Lewis CM, Boncoraglio GB, Lemmens R, Thijs V, Sudlow C, Wardlaw J, Rothwell PM, Meschia JF, Worrall BB, Levi C, Bevan S, Furie KL, Dichgans M, Rosand J, Markus HS, Rost N, International Stroke Genetics C (2016) Genome-wide meta-analysis of cerebral white matter hyperintensities in patients with stroke. Neurology 86:146-153

Tsaousi A, Williams H, Lyon CA, Taylor V, Swain A, Johnson JL, George SJ (2011) Wnt4/beta-catenin signaling induces VSMC proliferation and is associated with intimal thickening. Circ Res 108:427-436

Tucsek Z, Noa Valcarcel-Ares M, Tarantini S, Yabluchanskiy A, Fulop G, Gautam T, Orock A, Csiszar A, Deak F, Ungvari Z (2017) Hypertension-induced synapse loss and impairment in synaptic plasticity in the mouse hippocampus mimics the aging phenotype: implications for the pathogenesis of vascular cognitive impairment. Geroscience.

Ungvari Z, Tucsek Z, Sosnowska D, Toth P, Gautam T, Podlutsky A, Csiszar A, Losonczy G, Valcarcel-Ares MN, Sonntag WE, Csiszar A (2013a) Aging-induced dysregulation of dicer1dependent microRNA expression impairs angiogenic capacity of rat cerebromicrovascular endothelial cells. J Gerontol A Biol Sci Med Sci 68:877-891

Ungvari Z, Tucsek Z, Sosnowska D, Toth P, Gautam T, Podlutsky A, Csiszar A, Losonczy G, Valcarcel-Ares MN, Sonntag WE (2013b) Aging-induced dysregulation of Dicer1-dependent microRNA expression impairs angiogenic capacity of rat cerebromicrovascular endothelial cells. J Gerontol A Biol Sci Med Sci 68:877-891

Ungvari Z, Tarantini S, Kirkpatrick AC, Csiszar A, Prodan CI (2017a) Cerebral microhemorrhages: mechanisms, consequences, and prevention. Am J Physiol Heart Circ Physiol 312:H1128-H1143

Ungvari Z, Tarantini S, Hertelendy P, Valcarcel-Ares MN, Fulop GA, Logan S, Kiss T, Farkas E, Csiszar A, Yabluchanskiy A (2017b) Cerebromicrovascular dysfunction predicts cognitive decline and gait abnormalities in a mouse model of whole brain irradiation-induced accelerated brain senescence. Geroscience. 39:33-42

Ungvari Z, Tarantini S, Donato AJ, Galvan V, Csiszar A (2018) Mechanisms of vascular aging. Circ Res 123:849-867

Urbich C, Kuehbacher A, Dimmeler S (2008) Role of microRNAs in vascular diseases, inflammation, and angiogenesis. Cardiovasc Res 79:581-588

Verzola D, Milanesi S, Bertolotto M, Garibaldi S, Villaggio B, Brunelli C, Balbi M, Ameri P, Montecucco F, Palombo D, Ghigliotti G, Garibotto G, Lindeman JH, Barisione C (2017) Myostatin mediates abdominal aortic atherosclerosis progression by inducing vascular smooth muscle cell dysfunction and monocyte recruitment. Sci Rep 7:46362

Wang JC, Bennett M (2012) Aging and atherosclerosis: mechanisms, functional consequences, and potential therapeutics for cellular senescence. Circ Res 111:245-259

Wang A, Kwee LC, Grass E, Neely ML, Gregory SG, Fox KAA, Armstrong PW, White HD, Ohman EM, Roe MT, Shah SH, Chan MY (2017) Whole blood sequencing reveals circulating microRNA associations with high-risk traits in non-STsegment elevation acute coronary syndrome. Atherosclerosis. 261:19-25

Weber M, Kim S, Patterson N, Rooney K, Searles CD (2014) MiRNA-155 targets myosin light chain kinase and modulates actin cytoskeleton organization in endothelial cells. Am J Physiol Heart Circ Physiol 306:H1192-H1203

Wei Y, Schober A, Weber C (2013) Pathogenic arterial remodeling: the good and bad of microRNAs. Am J Physiol Heart Circ Physiol 304:H1050-H1059

Westerterp M, Bochem AE, Yvan-Charvet L, Murphy AJ, Wang N, Tall AR (2014) ATP-binding cassette transporters, atherosclerosis, and inflammation. Circ Res 114:157-170

Wezel A, Welten SM, Razawy W, Lagraauw HM, de Vries MR, Goossens EA, Boonstra MC, Hamming JF, Kandimalla ER, Kuiper J, Quax PH, Nossent AY, Bot I (2015) Inhibition of microRNA-494 reduces carotid artery atherosclerotic lesion development and increases plaque stability. Ann Surg 262: 841-847 discussion 847-8 
Wren JD, Garner HR (2004) Shared relationship analysis: ranking set cohesion and commonalities within a literature-derived relationship network. Bioinformatics. 20:191-198

Wu ML, Chen CH, Lin YT, Jheng YJ, Ho YC, Yang LT, Chen L, Layne MD, Yet SF (2014) Divergent signaling pathways cooperatively regulate TGFbeta induction of cysteine-rich protein 2 in vascular smooth muscle cells. Cell Commun Signal 12:22

Xing T, Du L, Zhuang X, Zhang L, Hao J, Wang J (2017) Upregulation of microRNA-206 induces apoptosis of vascular smooth muscle cells and decreases risk of atherosclerosis through modulating FOXP1. Exp Ther Med 14:4097-4103

Yamada Y, Nishida T, Horibe H, Oguri M, Kato K, Sawabe M (2014) Identification of hypo- and hypermethylated genes related to atherosclerosis by a genome-wide analysis of DNA methylation. Int J Mol Med 33:1355-1363

Yang ZY, Simari RD, Perkins ND, San H, Gordon D, Nabel GJ, Nabel EG (1996) Role of the p21 cyclin-dependent kinase inhibitor in limiting intimal cell proliferation in response to arterial injury. Proc Natl Acad Sci U S A 93:7905-7910

Yoshino J, Baur JA, Imai SI (2018) NAD(+) intermediates: the biology and therapeutic potential of NMN and NR. Cell Metab 27:513-528

Yu J, Qiu Y, Yang J, Bian S, Chen G, Deng M, Kang H, Huang L (2016) DNMT1-PPARgamma pathway in macrophages regulates chronic inflammation and atherosclerosis development in mice. Sci Rep 6:30053

Zampetaki A, Attia R, Mayr U, Gomes RS, Phinikaridou A, Yin X, Langley SR, Willeit P, Lu R, Fanshawe B, Fava M, Barallobre-Barreiro J, Molenaar C, So PW, Abbas A, Jahangiri M, Waltham M, Botnar R, Smith A, Mayr M (2014) Role of miR-195 in aortic aneurysmal disease. Circ Res 115:857-866

Zhang H, Zhang J, Ungvari Z, Zhang C (2009) Resveratrol improves endothelial function: role of TNF $\{$ alpha $\}$ and vascular oxidative stress. Arterioscler Thromb Vasc Biol 29:1164 1171

Zhang X, Azhar G, Wei JY (2012) The expression of microRNA and microRNA clusters in the aging heart. PLoS One 7: e34688

Zhang B, Day DS, Ho JW, Song L, Cao J, Christodoulou D, Seidman JG, Crawford GE, Park PJ, Pu WT (2013) A dynamic H3K27ac signature identifies VEGFA-stimulated endothelial enhancers and requires EP300 activity. Genome Res 23:917-927

Zhang F, Zhang R, Zhang X, Wu Y, Li X, Zhang S, Hou W, Ding Y, Tian J, Sun L, Kong X (2018) Comprehensive analysis of circRNA expression pattern and circRNA-miRNA-mRNA network in the pathogenesis of atherosclerosis in rabbits. Aging (Albany NY) 10:2266-2283

Zhao X, Wang Y, Meng C, Fang N (2018) FMRP regulates endothelial cell proliferation and angiogenesis via the miR181a-CaM-CaMKII pathway. Cell Biol Int 42:1432-1444

Zhu SB, Zhu J, Zhou ZZ, Xi EP, Wang RP, Zhang Y (2015) TGFbeta1 induces human aortic vascular smooth muscle cell phenotype switch through PI3K/AKT/ID2 signaling. Am J Transl Res 7:2764-2774

Zhu M, Zuo J, Shen J, Jing W, Luo P, Li N, Wen X, Wang C, Yu M, Liang C, Tu J (2016) Diagnostic potential of differentially expressed Homer1 and Homer2 in ischemic stroke. Cell Physiol Biochem 39:2353-2363

Zovoilis A, Agbemenyah HY, Agis-Balboa RC, Stilling RM, Edbauer D, Rao P, Farinelli L, Delalle I, Schmitt A, Falkai P, Bahari-Javan S, Burkhardt S, Sananbenesi F, Fischer A (2011) microRNA-34c is a novel target to treat dementias. EMBO J 30:4299-4308

Publisher's note Springer Nature remains neutral with regard to jurisdictional claims in published maps and institutional affiliations. 